January 2011

\title{
Does Judicial Philosophy Matter?: A Case Study
}

Francisco J. Benzoni

Christopher S. Dodrill

Follow this and additional works at: https://researchrepository.wvu.edu/wvlr

Part of the Judges Commons, Law and Philosophy Commons, and the Law and Politics Commons

\section{Recommended Citation}

Francisco J. Benzoni \& Christopher S. Dodrill, Does Judicial Philosophy Matter?: A Case Study, 113 W. Va. L. Rev. (2011).

Available at: https://researchrepository.wvu.edu/wvlr/vol113/iss2/4

This Article is brought to you for free and open access by the WVU College of Law at The Research Repository @ WVU. It has been accepted for inclusion in West Virginia Law Review by an authorized editor of The Research Repository@WVU. For more information, please contact ian.harmon@mail.wvu.edu. 


\title{
DOES JUDICIAL PHILOSOPHY MATTER?: A CASE STUDY
}

\author{
Francisco J. Benzoni* and Christopher S. Dodrill**
}

\begin{abstract}
A leading theory in the study of judicial behavior is the attitudinal model. This theory maintains that a judge's political ideology can be used to predict how a judge will decide certain cases; other factors, such as the judge's judicial philosophy, tend to be unimportant. Under this theory, two judges with the same political ideology, but different judicial philosophies, should virtually always vote the same way in cases with predicted ideological outcomes.

This manuscript tests the attitudinal model by examin ing opinions by two judges with very similar political ideologies but different judicial philosophies: Judge Michael Luttig and Judge Harvie Wilkinson III of the U.S. Court of Appeals for the Fourth Circuit. After defining the judges' political ideologies and judicial philosophies, this study examines "political" cases in which one of these judges wrote the majority opinion and the other dissented. The result of the study is that when these judges came to different conclusions in these ideological cases, it is likely they did so on the basis of their judicial philosophies. In short, contra the attitudinal model, at least in some cases judicial philosophy does matter.
\end{abstract}

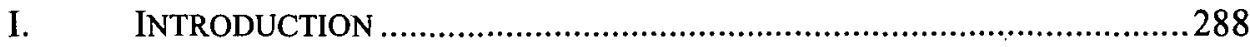

A. Design of Study ............................................................2289

B. $\quad$ Wilkinson and Luttig: Concurrence, Dissent, and Ambition ..291

C. Limitations...............................................................295

- Francisco J. Benzoni and Christopher S. Dodrill

* $\quad$ B.S., Cornell University; Ph.D., University of Chicago; J.D., Duke University.

** $\quad$ B.S., United States Naval Academy; J.D., Duke University.

The authors thank Jonas Anderson, Mitu Gulati, Sarah Hawkins, David Levi, Nick Linder, John Niles, and students in a workshop on Judicial Behavior at Duke University School of Law for their comments. Stefanie Lindquist gave invaluable empirical data on ideology. Any errors are ours alone. 


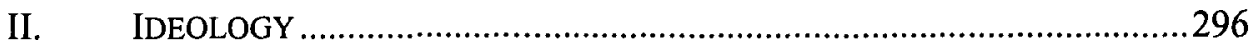

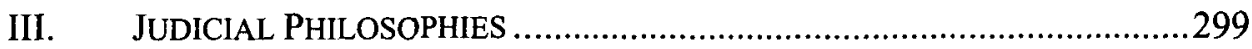

A. Judicial Activism ..................................................................299

B. Defining the Judicial Philosophies.........................................300

1. Judge Wilkinson ........................................................300

2. Judge Luttig .............................................................304

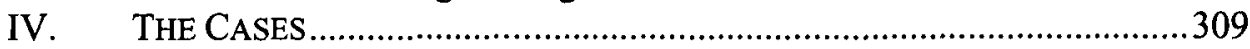

A. Gibbs v. Babbitt, 214 F.3d 483 (4th Cir. 2000) ......................310

B. United States v. Cotton, 261 F.3d 397 (4th Cir. 2001) ...........316

C. Berkley v. Common Council, 63 F.3d 295 (4th Cir. 1995) (en banc) ............................................................................... 318

D. First Penn-Pacific Insurance Co. v. Evans, 304 F.3d 345 (4th Cir. 2002) .......................................................................... 321

E. Dixon v. CSX Transportation, 990 F.2d 1440 (4th Cir. 1993)..................................................................................323

F. Fieldcrest Cannon, Inc. v. National Labor Relations Board, 97 F.3d 65 (4th Cir. 1996).......................................................327

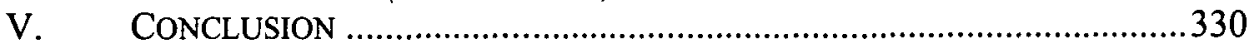

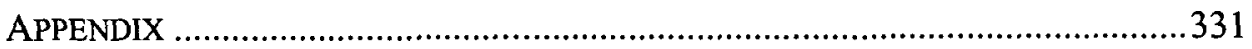

\section{INTRODUCTION}

A looming question in the study of judicial behavior is whether a judge's ideology is all that is necessary to predict outcomes to judicial decisions or whether factors such as judicial philosophy also matter. The attitudinal model, a dominant theory especially among political scientists, takes the view that judges vote their personal preferences. ${ }^{1}$ A judge's ideology, not a judge's judicial philosophy, attitudinalists argue, determines how a judge will decide a case. And, considering the Senate confirmation hearings of recent Justices appointed to the United States Supreme Court, Congress appears to share this view.

Although related, ideology and judicial philosophy are not identical. Ideology concerns outcomes and the way one thinks the world-and the lawought to be. A judicial philosophy is a chosen, articulable, and rationally defensible method of judicial decision-making that generally includes an explicitly articulated view of such things as the role and proper interpretation of the Constitution, the judiciary's place in our constitutional regime, the function of the law, the separation of powers, federalism, and how relevant sources are to be interpreted. $^{2}$ Still, certain judicial philosophies are attractive to certain ideolo-

1 See Jeffrey A. Segal \& Harold J. Spaeth, The Supreme Court and the Attitudinal MODEL REVISITED xv (2002) (using the attitudinal model to analyze U.S. Supreme Court justices).

2 See Randy E. Barnett, Cronyism: Alexander Hamilton Wouldn't Approve of Justice Harriet Miers, WALL ST. J., Oct. 4, 2005, at A26 for a similar understanding of the term "judicial philosophy." 
gies. For example, few "liberal" jurists are strict textualists. Nevertheless, because ideology is powerfully interwoven with one's view of the way things ought to be and judicial philosophy is a complex method of reasoning, we expect that, at least in some cases, they will lead to different outcomes.

Judicial philosophy may be important, for instance, when two judges with similar political ideologies, but different judicial philosophies, vote differently in cases with predicted ideological outcomes. The strict attitudinal model has difficulty explaining these kinds of cases. This study adds to the debate by comparing two judges with similar political ideologies but different judicial philosophies. It examines political cases, or cases with a determinable ideological outcome in which they voted opposite one another and analyzes the bases of their decisions. If judicial philosophy matters, then we expect the judges to decide cases in accord with their judicial philosophies, with at least one of the judges deciding contrary to his political ideology. In other words, when a judge's judicial philosophy suggests an outcome that differs from that of his political ideology, the outcome arrived at through his judicial philosophy should prevail.

\section{A. Design of Study}

In another study, Daniel Farber assessed whether theories of statutory interpretation matter in judicial decision-making. ${ }^{3}$ Farber analyzed statutoryinterpretation approaches between the Seventh Circuit's Judges Frank H. Easterbrook and Richard A. Posner and looked at cases where they dissented from one another. ${ }^{4} \mathrm{He}$ analyzed how they reached their decisions. ${ }^{5} \mathrm{He}$ concluded that theories of statutory interpretation do not matter; that the judges deviated from their avowed theories of statutory interpretation to get to a particular result. $^{6}$

Our study is similar to Farber's in some regards, but differs significantly in other respects. We examine two judges that served together for nearly fifteen years on the United States Court of Appeals for the Fourth Circuit: Judge Harvie Wilkinson III and Judge Michael Luttig. ${ }^{7}$ These judges bear some resemblance to the judges in Farber's study. Judge Wilkinson has a pragmatic streak, though, as we will see, he is not a devout pragmatist like Judge Posner. And

\footnotetext{
3 Daniel A. Farber, Do Theories of Statutory Interpretation Matter? A Case Study, 94 Nw. U. L. REV. 1409 (2000).

$4 \quad I d$.

$5 \quad$ Id.

$6 \quad$ Id. at $1429-34$.

7 Judge Luttig resigned from the Court of Appeals in 2006 and now works for the Boeing Corporation. Judge Wilkinson remains on the bench.
} 
Judge Luttig, like Judge Easterbrook, was a textualist, though he lacked Easterbrook's dedication to the law-and-economics paradigm. ${ }^{8}$

There are, however, two fundamental differences between Farber's study and our own. First, our study examines the judges' comprehensive judicial philosophies, not only their theories on statutory interpretation. This allows for comparison on a greater range of cases. Second, our design ensures that the judges' ideologies are central to our study. Unlike Farber, we do not simply seek to determine in the abstract if judicial philosophies are important in reaching conclusions. ${ }^{9}$ We have chosen cases with determinable ideological outcomes, so that, given the ideological similarity of the judges, one judge must have voted in a counter-ideological fashion. This design highlights the function of their respective judicial philosophies in reaching their decisions. Our conclusion, unlike Farber's, is that judicial philosophies do matter, at least in some cases.

Based on empirical data, their personal histories, and major-media opinion, both judges in our study are ideological conservatives. Yet they approached judging differently. Judge Luttig, on the one hand, was a devoted textualist with seemingly little concern with context outside the text of the governing law or precedent. Judge Wilkinson, on the other hand, while taking text seriously, also considers broader issues, such as separation of powers, federalism, public policy, and practical consequences.

Certain types of cases are perceived as more "political" than others. ${ }^{10}$ Cases involving criminal appeals, civil rights, labor issues, and economic regulation have predicted ideological outcomes." The "conservative" outcome in these cases is for the court to side with the prosecution in criminal cases, the defendant in civil-rights cases, business in labor cases, and the challenger in economic regulation cases. The "liberal" outcome is the opposite-with the defendant in criminal cases, the plaintiff in civil-rights cases, the employees in labor cases, and the government in economic-regulation cases. ${ }^{12}$ These "political" cases lend themselves to analysis because an attitudinalist would predict

8 In the end, Judge Posner's and Judge Easterbrook's similar biographies and shared beliefs on law and economics may pervade their entire judicial philosophies and bring their theories closer together than Farber maintains.

9 To put the point another way, we have a specific target in mind-the strict attitudinal model of judicial decision-making.

10 Kenneth L. Manning, Bruce A. Carroll, \& Robert A. Carp, George W. Bush's Potential Supreme Court Nominees: What Impact Might They Have?, 85 JUDICATURE 278, 280 (2002); see also Cass R. Sunstein, David SchKade, Lisa M. Ellman, \& ANDRES SaWicki, ARE JudGes POLITICAL? AN EMPIRICAL ANAL YSIS OF THE FEDERAL Judiciary 8 (2006).

1 Manning, Carroll \& Carp, supra note 10; see also SUSTEIN, SCHKADE, ElLMAN, \& SAWICKI, supra note 10 , at $17-19$.

12 Manning, Carroll, \& Carp, supra note 10, at 280; see also SUNSTEIN, SCHKADE, ELLMAN, \& SAWICKI, supra note 10, at 17-19. Sunstein et al. use a similar coding of cases, though they use more categories. See SUNSTEIN, SCHKADE, ElLMAN, \& SAWICKI, supra note 10, at 17-19. Using their greater number of categories, however, would not have yielded any more cases in our study. 
that judges of the same ideology would vote the same way. While this labeling is undoubtedly crude, for our purposes, the point is simply that the attitudinal model provides that these types of cases have an identifiable ideological outcome. Therefore, when the two judges vote for opposite outcomes, one or the other must be going against the grain of his ideology.

To analyze Judge Wilkinson's and Judge Luttig's decisions, we selected "political" cases in which one judge wrote the majority opinion and the other dissented within the above categories. ${ }^{13}$ We choose these cases because the judges were directly addressing one another. This produced six cases-one criminal appeal, one civil-rights case, two labor cases, and two economic regulation cases - for us to analyze.

\section{B. Wilkinson and Luttig: Concurrence, Dissent, and Ambition}

Judge Luttig and Judge Wilkinson rarely disagreed. During their time together on the Fourth Circuit, they heard 1099 cases together. Of these cases, 1003 were panel decisions and 96 were en banc decisions. Of the panel decisions, 158 were published. ${ }^{14}$ Of the published panel decisions, Judge Wilkinson and Judge Luttig dissented from each other a total of eighteen times. ${ }^{15}$ Judge Wilkinson, who dissented five times, had a dissent rate of $3.2 \%$. Judge Luttig, who dissented thirteen times, had a dissent rate of $8.2 \%$. While it might be argued that these low dissent rates simply reflect these judges' similar ideologies, these rates were actually higher than their overall dissent rates. Judge Wilkinson's overall dissent rate in published panel decisions was only $2.2 \%$ and Judge

13 We obtained these cases through a LexisNexis search. Within the Fourth Circuit database, we entered the search terms "JUDGES(Wilkinson and Luttig) and OPINIONBY(Wilkinson or Luttig) and DISSENTBY(Wilkinson or Luttig)." The search returned seven cases. One case is a non-political statutory interpretation case-Cabell Huntington Hospital v. Shalala, 101 F.3d 984 (4th Cir. 1996) - and is excluded from our analysis. Cabell Huntington Hospital involved neither an ideological outcome, nor did the judges rely on their judicial philosophies to reach their outcomes. The case turned on disagreement about which term Congress meant a particular parenthetical phrase to modify.

14 We use published panel decisions for our dissent rate comparisons between Judge Wilkinson and Judge Luttig for several reasons. First, the overall dissent rates for unpublished opinions for Judges Luttig and Wilkinson were so low (0.1\% for Judge Luttig and $0.2 \%$ for Judge Wilkinson) that any comparisons are difficult. Further, of the 854 unpublished opinions for which Judges Luttig and Wilkinson were on panels together, they dissented a total of one time (Judge Wilkinson dissented). That is a dissent rate of $0 \%$ for Judge Luttig and $0.1 \%$ for Judge Wilkinson. These cases are often uncontroversial and frequently decided by the panels via conference calls. Second, en banc decisions are generally more controversial and have a much higher dissent rate. But because there are often multiple dissents, it is not always less clear when two individual judges are directly dissenting against one another. (Judge Luttig's dissent rate on en banc decisions is $12.5 \%$, and Judge Wilkinson's dissent rate on en banc decisions is $4.8 \%$.)

15 In this manuscript, we explore a subset of these eighteen opinions, namely, those six of the seven opinions in which Judge Wilkinson or Judge Luttig actually wrote the majority opinion and the other dissented. See supra note 13, for an explanation of why we choose to exclude the seventh case. 
Luttig's overall dissent rate in published panel decisions was only 6.9\%. Thus, both Judge Wilkinson's and Judge Luttig's dissent rates actually increased slightly when they were on panels together. In comparison, the Fourth Circuit as a whole had a $15.2 \%$ dissent rate in published panel decisions during the relevant period. ${ }^{16}$

Competition, at least in part, might explain why the judges dissented from one another. The judges may have decided cases in order to play to a specific audience: the Bush White House. ${ }^{17}$ Both judges were serious contenders to fill Supreme Court vacancies. They may have dissented from one another to distinguish themselves and to signal to a conservative administration that they were the "right pick" to fill those vacancies.

In Judge Luttig's case, his dissent rates mask an important shift. Prior to President Bush's inauguration on January 20, 2001, Judge Luttig's overall dissent on published panel decisions was 5.5\%. Between President Bush's inauguration and Judge Luttig's resignation, however, Judge Luttig's overall dissent rate on published three-judge panel decisions jumped to $10.8 \%{ }^{18}$ Further, when Judge Luttig was on a three-judge panel with Judge Wilkinson, his dissent rate went from $4.6 \%$ pre-inauguration to $16.0 \%$ post-inauguration. Therefore, he went from dissenting less often when on a panel with Judge Wilkinson (preinauguration: $4.6 \%$ with Judge Wilkinson, compared with $5.5 \%$ overall) to dissenting considerably more often when on a panel with Judge Wilkinson (postinauguration: $16 \%$ with Wilkinson, compared with $10.2 \%$ overall). These are fairly dramatic changes in Judge Luttig's dissent rates, and especially when he was on a three-judge panel with Judge Wilkinson. Judge Wilkinson's dissent rate when on three-judge panels with Judge Luttig went from $2.8 \%$ preinauguration to $4.0 \%$ post-inauguration.

There is also some evidence of a subtle shift in judicial philosophy that accompanied Judge Luttig's increase in dissent rate-his decreasing use of legislative history (for either positive or deflecting purposes). From 1991-2006, Judge Luttig used legislative history approximately twenty-two times, but only five times from 2001 and later. His average annual rate of use of legislative history in published opinions dropped from 1.8 times pre-inauguration to 0.9

16 See Appendix for a summary of the statistics. Our time period begins when Judge Luttig issued his first decision as an appellate judge (12/26/1991) and ends when he resigned (05/11/2006).

17 Lawrence Baum, Judges and Their Audiences: A Perspective on Judicial Behavior 12 (2006). In his book, Baum briefly suggests that Judge Luttig may have tailored his judicial decisions in a way to separate himself from Judge Wilkinson in the Administration's eyes in order to increase his chances of promotion to the Supreme Court. Id. We have tried to correct for this by selecting cases across a number of years when the presidency and Congress were controlled by both political parties.

18 Judge Wilkinson's overall dissent rate on published panel decisions did not move, remaining at $2.1 \%$ both before and after the inauguration. 
times post-inauguration. ${ }^{19}$ This may indicate a hardening in his textualist approach, though it can hardly be considered a major shift. Any detectable shift in his position is probably slight.

Additionally, it is difficult to miss the increase in Judge Luttig's stinging rhetoric directed at Judge Wilkinson during this latter time frame, as well as Judge Wilkinson's replies. ${ }^{20}$ At times, Judge Luttig seemed to go out of his way specifically to criticize Judge Wilkinson. ${ }^{21}$ He increasingly used his dissenting opinions to criticize Judge Wilkinson's concurrences and used his concurring opinions to criticize Judge Wilkinson's dissents. ${ }^{22}$

There is little evidence to support an argument that Judge Wilkinson tailored his decisions to distinguish himself from Judge Luttig. He had already thoroughly staked out his judicial philosophy in extra-judicial writing by 2001 , and the data indicates little change in his behavior. So does Judge Luttig's changing dissent rate and his hardening judicial philosophy indicate that he shifted his position in order to make himself as appealing a Supreme Court candidate as possible? There is hardly enough data to come to such a sweeping conclusion.

Furthermore, it is a heavy charge to say that a federal judge would decide a case to be poised for elevation to the Supreme Court. Further, it is also unclear precisely how one would signal that he was the "right pick." For example, which decisions in which types of cases send the "right" signal? The most obvious answer is to vote conservatively, but both these judges already voted conservatively. In order to distinguish themselves from each other, did one

19 Further, most of these later uses were defensive or deflecting uses to defeat a point made by the other side, rather than a positive use that actually furthered his own position.

20 For example, in a 2004 en banc decision, McMellon v. United States, 387 F.3d 329, 376-82 (4th Cir. 2004), Judge Luttig, in a dissent that spans over fifty pages, expended considerable energy in criticizing Judge Wilkinson's slim concurrence, arguing that Wilkinson "approaches decision of the question before us as if he were an interested legislator, rather than a neutral interpreter;" that he has created a "strawman;" engaged in "convenient hyperbole;" has a "misplaced view of the question," engages in "sleight of hand;" made a suggestion that is "incredible as a judicial observation;" used "analytically meaningless" analysis; and engaged in a "statutory frolic." In another en banc decision, Humphries v. United States, 397 F.3d 206, 227 (4th Cir. 2005), Judge Luttig wrote a concurrence (he concurred with the majority's judgment and opinion) for the express purpose of taking issue with Judge Wilkinson's dissent. He began by ridiculing Judge Wilkinson's characterization of the case and then went on to argue that "the dissent raises three flatly untenable arguments." Humphries, 397 F.3d at 227, 230. In Belk v. Charlotte-Mecklenburg Board of Education, 269 F.3d 305, 366 (4th Cir. 2001), Judge Luttig maintained that "Judge Wilkinson misunderstands this issue altogether . . ." See also Alan Cooper, Rivalry on Fourth Circuit? Wilkinson, Luttig Focus of Speculation, RichMOND TIMES-DISPATCH, Aug. 7, 2000, at B1 (speculating that competition for a Supreme Court seat may have driven Judges Wilkinson and Luttig to disagree).

21 See, e.g., Humphries, 397 F.3d at 230 (4th Cir. 2005); McMellon, 387 F.3d at 376-82 (4th Cir. 2004); Belk, 269 F.3d at 366 (4th Cir. 2001).

22 See, e.g., Humphries, 397 F.3d at 203; McMellon, 387 F.3d at 376-82; Belk, 269 F.3d at 366 . 
judge, then, vote for the liberal outcome? This might distinguish that judge, but hardly in way that would be likely to impress the Bush Administration.

Perhaps that the most plausible explanation of how these judges, or at least Judge Luttig, sought to distinguish themselves from one and another was to disagree as vociferously as possible whenever their judicial philosophies drove them (or even potentially drove them) in different directions. This might both serve to distinguish themselves by highlighting their differing judicial philosophies-especially Judge Luttig's philosophy which seemed to evolve at the same time-without having to make the dubious and unsupported assumption that the actual outcome they chose was dictated by any attempt to impress the audience that would be making the decision of who to nominate for Supreme Court. Still, it might cause them to emphasize their differences, perhaps dissenting more often against each other once President Bush took office. ${ }^{23}$ This interpretation implies that their respective judicial philosophies may have become more important to their reasoning in cases as they sought to distinguish themselves.

While this argument reinforces the position in this manuscript-that judicial philosophy matters in a causal sense-it also adds a significant caveat. Judicial philosophies themselves are, to some extent, malleable. The degree to which a judge adheres to his chosen philosophy may be influenced by outside factors, such as ambition and a felt need to differentiate oneself.

Another factor that may influence a judge's adherence to his chosen philosophy is public commitment to that philosophy, whether through judicial or extra-judicial writings. Judge Wilkinson, for instance, has a fairly comprehensive judicial philosophy to which he had committed himself in extra-judicial writings. Judge Luttig, likewise, had a fairly well-developed judicial philosophy, though it is almost exclusively contained his judicial writings. There is a large literature in psychology which demonstrates that publicly committing oneself to a certain position leads to consistency in action. ${ }^{24}$ Therefore, a judge who publicly endorses a given judicial philosophy may be more likely to follow that philosophy faithfully, even when it conflicts with his ideology. And as noted above, in addition to this more or less public commitment, Judge Luttig may also have been motivated to highlight his philosophy for strategic reasons-as a means of signaling to the Bush Administration his readiness to assume a role on the Supreme Court. ${ }^{25}$ Both judges in this study were highly motivated-because

23 And, in the case of Judge Luttig, the data bears this out. BAUM, supra note 17.

24 See, e.g., Robert B. CIALDINI, INFluence: SCIENCE AND PRACTICE (4th ed. 2001). In Chapter 3, Cialdini cites numerous studies that demonstrate that once people take a stand, they face considerable pressure to act in a manner consistent with that commitment. Id. at 52-97. Much of the pressure they feel is internal pressure to live up to their commitment. Id.

25 BAuM, supra note 17. Of course, the motivation to distinguish themselves from one another in order to appeal to a Republican Administration, if such motivation existed, would have been strongest in cases decided during or after 2001 (or, perhaps, 2000 in anticipation of a Republican administration). Of the cases that we analyze, two were decided in 2001 or later, and one was decided in 2000 . It is difficult to determine if the later decisions more powerfully showcase the 
of public commitment and perhaps because of ambition-to adhere to their chosen philosophical outlook.

An additional possible explanation for the judges' dissents from one another is personal animus. But it seems dubious to claim that such animus drove two federal judges to decide cases in a certain direction. It seems more plausible that such animus, if it existed, would make them be extra careful in their reasoning, knowing that the other is going to look to exploit any legal or logical hole in the argument. Further, it is one thing to argue that it is likely there was some animus between these judges, but quite another to argue that this animus influenced the way they voted in particular cases. This latter claim makes the dubious assumption that personal animus so interfered with their judicial reasoning process that their personal feelings toward each other drove them to harm one of the parties before them. Any personal animus may have colored the language they used, but it seems unlikely that it drove their actual decisions. To the contrary, as noted, it would seem more likely that it would heighten their attention to the tightness, logic, and legal grounding of their positions.

\section{Limitations}

Our study has several limitations. First, there is an inherent conservative bias in selecting which judges to analyze. We sought two judges of the same ideology, yet different judicial philosophies. "Conservative" judges seem to publicly subscribe to particular judicial philosophies more often than liberal, or even less-conservative, judges.

Second, as noted, ideology and judicial philosophy are not completely separate concepts. Adhering to a particular judicial philosophy tends to correlate with a particular ideology. For example, few, if any, modern "liberal" judges extol the virtues of strict textualism. ${ }^{26}$ One cannot therefore confidently conclude a judge decided a case based solely on judicial philosophy and apart from that judge's ideology. Still, there seem to be cases where a judge departs significantly from his ideology because of his judicial philosophy.

Finally, while Judge Wilkinson has written extensively on his judicial philosophy, Judge Luttig's non-judicial writings are minimal. We thus relied primarily on Judge Luttig's judicial opinions to pinpoint his judicial philosophy. There is an inherent paradox in doing so: we risk using opinions to determine philosophy and then using that philosophy to analyze opinions. We have tried to account for this issue by separating the cases we use to clarify the judges'

judges' differences in judicial philosophy, in part, because the issues and facts vary from case to case. Still, we argue, these differences are present and important in the judges' decision-making.

26 This could just be the times in which we live. Justice Hugo Black, a "liberal" judge, has often been considered a textualist. See Paul Killebrew, Where Are All the Left-Wing Textualists?, 82 N.Y.U. L. REV. 1895, 1899 (2007) (discussing the non-inevitability of textualism being an exclusively conservative approach). 
judicial philosophies from the cases that we use to discover whether the basis for their decisions is their differing philosophies.

While these limitations are important, our analysis minimizes their impact on our conclusions. This study has a simple design. We begin with judges of similar ideology, clarify the judges' philosophies, and analyze cases where they dissent from one another. This simple design, as well as the clarity of both judges' reasoning in the analyzed cases, makes it plausible to determine whether judicial philosophy matters to outcomes.

Part II of the manuscript looks at the judges' ideologies, labeling both ideologically "conservative." Part III outlines the judicial philosophies of each judge. Part IV examines "political" cases where either Judge Wilkinson or Judge Luttig wrote a majority panel opinion, but the other disagreed. Part V concludes.

\section{IDEOLOGY}

Judge Richard Posner has written that "politically like-minded judges usually vote the same way despite their different judicial philosophies. . . . They supply not 'actionable' reasons but rationalizations for actions taken on other grounds . . .."27 To address whether political ideology, rather than judicial philosophy, guides a judge's decision in a case, we first sought two judges with the same political ideologies. We are less concerned with identifying some or other ideology (e.g., "liberal" or "conservative") and more concerned with showing that the two judges share a relatively narrow bandwidth on the ideological spectrum. As conservatives, Judge Luttig and Judge Wilkinson meet this requirement.

Objectively defining "conservative" is not an easy task. The mere act of defining the word tends to reflect the ideology of the person attempting the definition. To label Judge Wilkinson and Judge Luttig, we used empirical coding, personal biographies, and opinions from major national newspapers. For empirical coding, we used both the Giles, Hettinger, and Pepper ideological score for the judges, ${ }^{28}$ as well as a study by Manning, Carroll, and Carp measuring the ideologies of short-list candidates President Bush was considering for a position on the U.S. Supreme Court. ${ }^{29}$

The Giles, Hettinger, and Pepper score determines a judge's ideology based on a complex ideological measure of that judge's home-state senator, when that senator is of the same party as the appointing President, or of the appointing President when the home-state senator is of a different party than the

\footnotetext{
27 Richard A. Posner, How Judges Think 346 (2008). Judge Posner suggests a study such as this to determine whether philosophy matters. Id. He predicts that it does not. Id.

28 Data provided by Stefanie Lindquist of Vanderbilt University (on file with authors).

29 Manning, Carroll, \& Carp, supra note 10, at 280-84. The study compared Judges Wilkinson and Luttig, as well as Judges (then-Justice) Brown, Easterbrook, Garza, and Jones. Id. at 281.
} 
appointing President. ${ }^{30}$ The data reveals that Judge Wilkinson and Judge Luttig are firmly on the conservative side of the line. The dataset has a base of zero ("politically neutral"), and ranges from -1 ("liberal") to +1 ("conservative"). Judge Wilkinson and Judge Luttig have scores of 0.269 and 0.259 , respectively. Comparison with other federal courts of appeals judges may be helpful to illustrate their ideologies. At the far "conservative" side is the Seventh Circuit's Judge Easterbrook, who has a score of 0.568 ; on the far "liberal" side is Judge Reinhardt on the Ninth Circuit, who has a score of -0.443 . Thus, Judge Wilkinson and Judge Luttig fall within the solidly conservative end of the spectrum.

Additionally, the Manning, Carroll, and Carp study compared decisions by several short-list candidates, including Judge Wilkinson and Judge Luttig, in the areas of criminal-justice, civil-rights, and economic- and labor-regulation. ${ }^{31}$ A "conservative" vote sided against defendants, civil-rights plaintiffs, and labor unions and government regulators, respectively. ${ }^{32}$ A "liberal" vote went the other way. ${ }^{33}$ That study placed Judge Wilkinson and Judge Luttig to the right of the average federal court of appeals judge. Judge Wilkinson voted for a "conservative" outcome $79.5 \%$ of the time, while Judge Luttig voted conservatively in $68.2 \%$ of cases. ${ }^{34}$ The average court of appeals judge voted conservatively $64.4 \%$ of the time. ${ }^{35}$ Interestingly, Judge Luttig was' the more "liberal" of the two judges: Judge Wilkinson voted for the conservative outcome more often than Judge Luttig in every category. ${ }^{36}$

Furthermore, personal biographies of the judges before they came to the bench help determine the judges' political ideology. Self-identification with a particular political party is a particularly helpful measure of a judge's ideology,

30 See Michael W. Giles, Virginia A. Hettinger, \& Todd Peppers, Picking Federal Judges: $A$ Note on Policy and Partisan Selection Agendas, 54 POL. RES. Q. 623, 627 (2001). The Giles, Hettinger, and Pepper score is a nuanced measure of ideology. It takes into account the senatorial courtesy that Presidents grant home-state senators in selecting judicial nominees by measuring the legislative voting records of the pertinent senators. Id. It also incorporates the political context surrounding a judge's nomination. Id.

31 Manning, Carroll \& Carp, supra note 10, at 280-84.

$32 \quad I d$. at 282.

33 Id. at 280-82. The Manning, Carroll, and Carp study applied data from the Songer Court of Appeals Database.

$34 \quad$ Id. at 282.

$35 \quad I d$.

36 Id. at 282. Manning, Carroll, and Carp found that, through 2002, Judges Luttig and Wilkinson voted for the conservative outcome in these types of cases more than the average federal court of appeals judge. Id. They voted for the conservative outcome $78.8 \%$ and $87.0 \%$ in criminaljustice cases; $66.7 \%$ and $76.9 \%$ in civil-rights cases; and $59.2 \%$ and $74.5 \%$ in economic- and labor-regulation cases, respectively. $I d$. The average federal court of appeals judge voted for the conservative outcome $77.7 \%$ in criminal-justice cases, $57.6 \%$ in civil-rights cases, and $57.8 \%$ in economic- and labor-regulation cases. Id. Judge Wilkinson has hinted that he questions the validity of this definition of conservative, and he is concerned over the implications of what he describes as stereotypes. J. Harvie Wilkinson III, Why Conservative Jurisprudence is Compassionate, 89 VA. L. REV. 753, 757 (2003). 
and Judge Wilkinson ran as a Republican candidate for the U.S. House of Representatives while in law school. ${ }^{37}$ He has also published numerous scholarly articles in defense of conservatism. 38 Both men clerked for "conservative" judges: Judge Wilkinson clerked for Justice Powell on the U.S. Supreme Court; Judge Luttig clerked for then-Judge Scalia on the D.C. Circuit and for Chief Justice Burger on the U.S. Supreme Court. ${ }^{39}$ Additionally, before their appointments, both men served as political appointees in Republicanadministration Justice Departments, ${ }^{40}$ and both were appointed to the bench by Republican presidents: Judge Wilkinson by Ronald Reagan and Judge Luttig by George H. W. Bush. ${ }^{41}$

Finally, major media has identified the judges as conservatives. President George W. Bush vowed to appoint conservative jurists to the Court, ${ }^{42}$ and Judge Wilkinson and Judge Luttig were among the most mentioned as short-list candidates by major print media. In a survey by the University of Pittsburgh Law School, Judge Luttig was the most frequently mentioned, non-associatejustice candidate to fill Justice Rehnquist's seat, while Judge Wilkinson was the fifth most-frequently-mentioned. ${ }^{43}$ A database search of major newspapers revealed twenty-six articles that mentioned Judge Luttig as a short-list candidate, while five listed Judge Wilkinson. ${ }^{44}$

37 Judicial Biography of J. Harvie Wilkinson III, FEDERAL JUdICIAL CENTER, http://www.fjc.gov/servlet/nGetInfo?jid=2587\&cid=999\&cytype=na8inState=na (last visited Oct. $26,2010)$.

38 See Wilkinson, supra note 36; J. Harvie Wilkinson III, Is There a Distinctive Conservative Jurisprudence?, 73 U. COLO. L. REV. 1383 (2002).

39 Judicial Biographies of J. Michael Luttig and J. Harvie Wilkinson III, FeDERAL JudiCiaL CENTER, http://www.fjc.gov/public/home.nsf/hisj (last visited March 13, 2008) (enter "Luttig" or "Wilkinson," respectively).

40 Judge Wilkinson was Deputy Assistant Attorney General in the Department of Justice Civil Rights Division from 1982-83. Id. Judge Luttig was principal deputy assistant attorney in the Office of Legal Counsel from 1989-90, and then assistant attomey general in OLC from 1990-91, as well as Counselor to the Attorney General from 1990-91. Id. Judge Luttig also worked in the Ford White House between college and law school. Id.

41 Id.

42 See Elisabeth Bumiller, Bush Vows to Seek Conservative Judges, N.Y. TIMES, Mar. 29, 2002, at A1 (quoting President Bush) ("We've got to get good, conservative judges appointed to the bench and approved by the United States Senate."); see also Robert A. Carp, Kenneth L. Manning, \& Ronald Stidham, The Decision-Making Behavior of George W. Bush's Political Appointees, 88 JUDiCATURE 20 (2004) (finding that Bush judicial appointees are "among the most conservative on record").

43 Possible Bush Nominees, JuRIST: ThE LEgal EdUCATION NETwORK, http://jurist.law.pitt.edu/mentions.htm (last visited Oct. 26, 2010).

44 These searches used newspapers from January 20, 2001, when Bush became President, through March 13, 2008. Within Lexis' "major newspaper" database, we used the following search terms: For Judge Wilkinson, we used the search terms "Wilkinson" w/s "short-list" w/s "Supreme Court." For Judge Luttig, we used the search terms "Luttig" w/s "short-list" w/s "Supreme Court." Judge Luttig's numbers are much higher than Judge Wilkinson's because of the press coverage of his resignation from the bench in 2006 and subsequent career at Boeing. 
Given these proxies for ideology, Judge Wilkinson and Judge Luttig can be fairly labeled "conservatives." Again, pinpointing their exact ideologies is not important; what matters is that the two judges share a similar ideology. Given a shared ideology, the attitudinalist model would predict that they would vote the same way in politically-charged cases.

\section{JUDICIAL PHILOSOPHIES}

Though they disagreed infrequently, it is instructive to examine precisely the grounds on which they did disagree. Such an examination sheds light on the way judicial philosophies can influence a judge's decision-making.

\section{A. Judicial Activism}

A fruitful place to begin an exploration of Judge Luttig's and Judge Wilkinson's judicial philosophies is through each judge's understanding of the justifiability of "judicial activism." Quite simply, Judge Luttig maintained that judicial activism is never justified, while Judge Wilkinson holds that judicial activism is justifiable under certain circumstances.

However, their different views on the justifiability of judicial activism are easily explained: they employed different definitions of "judicial activism." Judge Luttig maintained that judicial activism occurs whenever a judge inserts personal preferences or ideology into judicial decision-making. ${ }^{45}$ Judge Wilkinson offers a broader view, believing that judicial activism occurs whenever the judiciary intervenes in the democratic process. ${ }^{46}$

But this easy explanation masks the true import of the judges' disagreement. Given Judge Luttig's definition, the vast majority of judgesperhaps all judges-would agree that judicial activism so understood cannot be justified. However, Judge Luttig's definition excluded intervention with the democratic process. His judicial philosophy focused on rigorously analyzing text before him; he followed the conclusion to which that analysis led him. He was not independently concerned with invention in, or deference to, the democratic process. Whatever deference the judiciary owes the democratic process is,

\footnotetext{
45 "Judicial activism, properly defined," Judge Luttig maintained, "is simply the substitution of a judge's personal predilections for law, whatever form that substitution takes. That is, judicial activism exists whenever the judicial officer gives effect to his view of what law ought to be, rather than what law actually is." J. Michael Luttig, Remarks at the Conference of the American Constitution Society on Conservative Judicial Activism (Aug. 1, 2003), available at http://www.acslaw.org/pdf/Judicial\%20Activism.pdf (last visited March 15, 2008).

46 Judge Wilkinson argues, "All manifestations of activism involve by definition judicial intervention into the democratic process. For this reason, the Court's activist ventures must rest not only on a sound legal foundation, but on a profound sense of judicial modesty and caution." $J$. Harvie Wilkinson III, Is There a Distinctive Conservative Jurisprudence?, 73 U. CoLO. L. REV. 1383,1386 (2002).
} 
on his judicial philosophy, already built into to the judiciary's constitutional role of interpreting, and not making, law.

Wilkinson defines judicial activism in a way that brings deference to the democratic process and judicial modesty to the center of his judicial philosophy. To him, judicial intervention in the democratic process is only justified on the basis of sound legal principles and a profound sense of judicial modesty and caution.

\section{B. Defining the Judicial Philosophies}

\section{Judge Wilkinson}

Judge Wilkinson's threshold question is not "How should I resolve this case?" 47 Rather, it is, "To whom does the Constitution entrust the resolution of this issue?" In other words, he believes the judge must first consider whether the judiciary or the elected branches should decide an issue. And if the elected branches should decide the issue, the judiciary may be called upon to determine which branch is the most appropriate, both horizontally (executive vs. legislature) and vertically (federal vs. state). If the judiciary is to go beyond this determination and intervene in the democratic process, it should, as noted, do so with appropriate deference and modesty.

Judge Wilkinson's judicial philosophy keeps the democratic processes central by deference to the elected branches through judicial modesty. He believes that it is "a grave judicial act to nullify a product of the democratic process." ${ }^{, 49}$ When the judiciary invalidates an act by an elected branch, it raises the specter of unjustified judicial activism. Judge Wilkinson integrates this deference with fidelity to the text of the Constitution and statutes, including both the guarantee of rights and the structure of the relation between state and federal governments and between the branches of the federal government. Of course, there are times when this deference and fidelity come into tension. But a crucial component in the democratic process is the Constitution's "structural" dictates. "Structural" pertains to "those provisions that appear to direct responsibility for a decision to a particular branch of the federal government or to the states," well as "the place of the federal courts in relation to the Congress, the executive branch, and the various states." fer "the priceless values of self-governance upon many different entities." 52

\footnotetext{
47 J. Harvie Wilkinson III, Our Structural Constitution, 104 CoLUM. L. REV. 1687, 1707 (2004).

$48 \quad I d$

49 Brzonkala v. Va. Polytechnic Inst. \& State Univ., 169 F.3d 820, 890 (4th Cir. 1999) (Wilkinson, J. concurring).

so Wilkinson, supra note 47 , at 1688 .

$51 \quad$ Id. at 1689.

$52 \quad$ Id. at 1706.
} 
Judge Wilkinson believes, for instance, that the Rehnquist Court was justified in striking down numerous federal laws because the Court's "interventions . . . have invalidated congressional enactments violating basic principles of structure, namely the sovereign rights of states." 53

Still, Judge Wilkinson recognizes that such activism can be "heady wine." 54 He emphasizes that judicial interference with legislative decisions should be rare because the Constitution "suggests a sense of judicial modesty and restraint, and abjures acts of aggrandizement on the part of the judiciary." 55 Judge Wilkinson believes judicial restraint is required for the democratic polity to negotiate controversial societal issues. Judge Wilkinson made this point in an article arguing against constitutionalizing the issue of same-sex marriage. He explained that by constitutionalizing issues, we remove them from the democratic debate. ${ }^{56}$ Such constitutionalization gives too much power to the courts, Judge Wilkinson argued, and upsets the delicate balance between the judiciary and the elected branches. This balance is essential to the functioning of our constitutional system. ${ }^{57}$ The Constitution is, on Judge Wilkinson's understanding, a framework for democratic rule, and not a document "to enshrine every value we hold dear." 58 The Framers, Judge Wilkinson believes, "were concerned supremely with process, and that process has made possible our civility, self-governance, and greatness as a democratic nation."59

Judge Wilkinson views federalism as a core value of our constitutional regime. ${ }^{60}$ When deferring to the democratic process conflicts with the values of

53 Id. at 1690. As he put it elsewhere, "The Rehnquist Court has not . . sought to preempt the workings of democracy." Wilkinson, supra note 46, at 1385.

54 Wilkinson, supra note 46, at 1400.

55 Wilkinson, supra note 47 , at 1695.

56

Misuse of constitutions is not an academic point. By traducing the American constitutional tradition [by proposing a constitutional ban on same-sex marriages], we are eroding not only our sovereign rights to self-governance, but our ability as a society to debate our deepest differences with even a modest measure of mutual respect.

J. Harvie Wilkinson III, Gay Rights and American Constitutionalism: What's a Constitution For?, 56 DUKE L.J. 545, 545 (2007).

57

The Framers conducted a revolution in favor of self-governance, however, and they were well aware that using a constitution to deny future generations the ability to rule themselves would threaten the charter's legitimacy. . . [The Framers] drafted, first and foremost, a framework for majoritarian rule in the present, which enables self-governance rather than undermining it.

Id. at 557-58.

$58 \quad$ See id. at 558.

59 Id. at 580 .

60 Wilkinson wrote, 
federalism, courts are in a particularly difficult position. They must determine which democratic institution-state or federal-should have decision-making power over the issue at hand. Courts must act both with restraint to respect and preserve the democratic process and with rigor to uphold the values of federalism by checking the federal government's extension of power. A judge should be a "structural referee, not an ideological combatant." 61 Judge Wilkinson sees the Constitution as not only guaranteeing individual rights, but also setting a complementary structure of powers divided between federal and state governments and between branches of the federal government. ${ }^{62}$ These structural elements of the Constitution complement guaranteed rights because diffusing power serves to guarantee rights. ${ }^{63}$

Upon deciding the threshold question of to whom the Constitution entrusts resolution of the issue, Judge Wilkinson's philosophy takes on a practical bent. He advocates a "jurisprudence of presumptions," rather than a strict rulebased approach, which admits of no exceptions, or an equity-based approach, which decides cases on the basis of a sense of enlightened decency. ${ }^{64}$ The advantages of the strict rule-based approach are that it facilitates predictability and ease of application, and it minimizes judicial discretion. ${ }^{65}$ The advantage of the equity-based approach is that it is highly sensitive to individual circumstances. ${ }^{66}$ The problem with a strict rule-based approach is that, in human life, there truly are exceptional circumstances that demand exceptions. ${ }^{67}$ And the problem with an equity-based approach is that it lacks the predictability necessary for the legal system to function efficiently. ${ }^{68}$ A "jurisprudence of presumptions," Judge Wilkinson believes, avoids these problems by providing general rules, which allow exceptions in certain circumstances. ${ }^{69}$ It seeks to combine the strengths of the

[T] he problem with the Warren and Burger Courts' vision was an absence of attention to the intermediate levels of America - to our mediative institutions, both public and private, to the vast constitutional in-between. . . . In a public sense, the mediative and intermediate institutions are our state and local governments. And it is precisely because of the growing dominance of national and international forms of governance that they become important for our future.

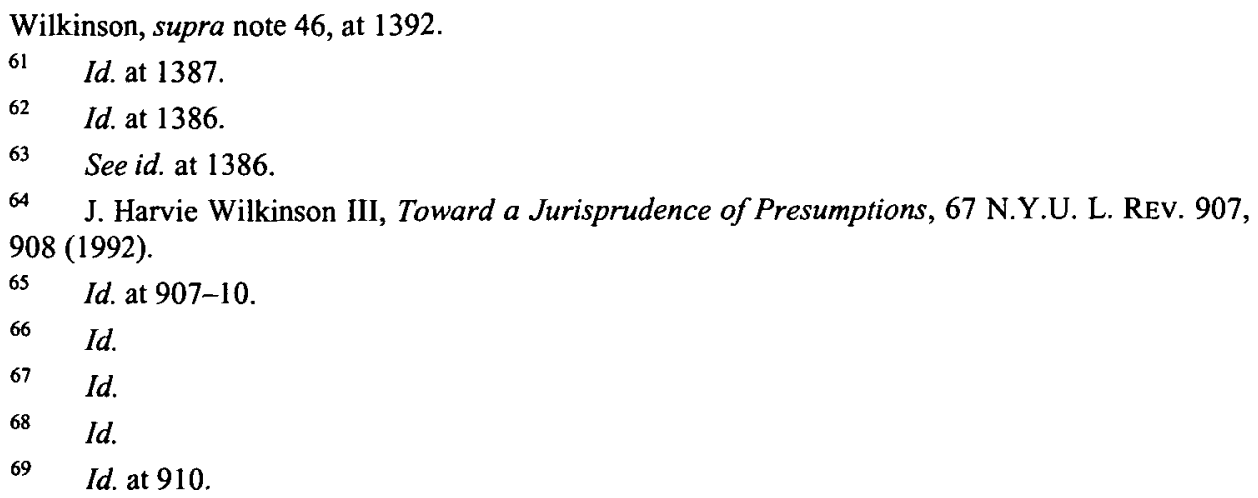


rule-based and equity-based perspectives, while avoiding their problems. ${ }^{70}$ It rescues the harsher applications of the rules-based approach by allowing for exception, while simultaneously restricting the dispensation of equity to those cases that are truly are exceptional. ${ }^{71}$ The rule to be applied in a particular case is a strong presumption that can be overcome, though rarely and only by meeting the very high threshold of being "exceptional.",

Yet another aspect of Judge Wilkinson's concern with context is the attention he pays to the practical consequences of judicial decision-making. Judge Wilkinson says judges must take consequences seriously if compassion is to be disciplined by reason so that it can be effectively deployed. ${ }^{73}$ To him, democracy and the Constitution's structure highlight the importance of the consequences of judicial decision-making. They focus on how judicial decisions will affect the elected branches and the proper allocation of decision-making power among them. ${ }^{74}$ Judge Wilkinson's concern about the structural responsibilities of the judiciary in a democratic regime acts as an important and independent rationale for his decision-making.

If Judge Wilkinson's judicial philosophy has a causal impact on his decision in a given case, we expect that the following factors, in appropriate circumstances, were integral in reaching his decision: $:^{75}$

(1) Deference given to the democratic branches coupled with (and sometimes in tension with) a powerful concern with the structural dictates of the Constitution;

(2) Rules are employed as presumptions, such that equity plays a role in his decisions in exceptional circumstances;

\footnotetext{
70 Wilkinson, supra note 64 , at 911.

71 Id.

72 Id.

73 Wilkinson, supra note 36 , at 761.

74 For instance, in McMellon v. United States, 387 F.3d 329, 338 (4th Cir. 2004) (Wilkinson, J., concurring), the en banc Fourth Circuit held that the waiver of sovereign immunity in the Suits in Admiralty Act includes an implied discretionary-function exception. Judge Wilkinson wrote a concurrence focusing on the negative consequences to the executive branch if the court failed to find an implied discretionary function waiver. Id. To him, part of the judiciary's role in the democratic regime, within the "structural" Constitution, is to protect the proper decision-making province of the different branches-and the different levels-government. Id. When the court can justifiably read in an implied discretionary function exception to the waiver of sovereign immunity, and such an exception is important to the proper functioning of the executive branch, the court must do so. Id. at 350-53. See infra Part II(B)(2) for an explanation of how Judge Luttig responded to this argument.

75 That is, without the deployment of some or all of these factors, it is doubtful that he would have reached the decision that he did.
} 
(3) Similarly, facts are interpreted contextually (for instance, analysis of these facts are informed by the larger social and political context); and

(4) Practical consequence of decision, particularly its impact on democratic institutions, is an important consideration.

\section{Judge Luttig}

Judge Luttig saw his judicial role in a democracy as faithfully interpreting the text before him, and he adhered to a more rules-based approach. ${ }^{76}$ The democratic process or the consequences of judicial decision-making (either on that process or more generally) were subordinated to this primary task and did not serve as independent guides or criteria in judicial decision-making.

Interestingly, this did not mean Judge Luttig's judicial philosophy was more restrained or deferential than Judge Wilkinson's. On the contrary, Judge Luttig was less concerned with restraint and deference and more focused on textual analysis. He confined his definition of judicial activism to the impermissible act of allowing personal ideology influence judicial decision-making. ${ }^{77}$ Judge Luttig's understanding of activism did not include decisions that overturn judgments the elected branches; he was not at pains to justify such decisions. Modesty and deference played a diminished role in his judicial philosophy.

The text-statutory or constitutional-was central to his philosophy. "[L]aw," Judge Luttig explained, "is an institution, separate and apart from politics." J8 Judges are "charged with the sacred responsibility of [the] interpretation" of the law and, upon donning their judicial robe, "must forsake their personal politics." They "begin and end with rules, and that's what we do and talk about it." ${ }^{\prime 80}$ It is by and through this single-minded focus on the text, coupled with intellectual rigor and honesty, that "the judicial result reached be the expression, not of the politics of the particular judge, but of the politics of the People, from whom the judge derives his power." ${ }^{81}$ A lack of intellectual

76 Judge Luttig used legislative history only thirty-four times in published decisions throughout his time on the bench, and only seven times since 2000 . Interestingly, in those occasions that he used it after the year 2000 , he used legislative history only to undermine the opposing judges' characterizations of that legislative history.

77 He distinguished his definition of judicial activism from Judge Wilkinson's. He stated that Judge Wilkinson believed that "if a court overturns an act as unconstitutional, that is an act of judicial activism, without prescription, whether good or bad, it's just a fact." Luttig, supra note 45 , at 34 . He continued, "I personally don't share that view." Id.

78 Id. at 19.

79 Id.

80 Id. at 32. Judge Luttig argues that he does not have much trouble separating his personal politics from his judicial decision-making. Id.

81 Id. 
rigor, in his judgment, may either indicate incompetence or signal that political preference has interfered with judicial decision-making. ${ }^{82}$

Judge Luttig offered a gloss on his understanding of the judicial task in interpreting statutes in Nigh v. Koons Buick Pontiac GMC, ${ }^{83}$ a statutoryinterpretation case. He emphasized that courts should look to the statutory text alone to determine congressional intent. ${ }^{84} \mathrm{He}$ wrote,

Our responsibility is . . . not to determine whether there is evidence that "Congress intended to override the Fourth Circuit's" precedent (or any circuit precedent for that matter). . . . The questions before this court, and that which we address above, are simply whether Congress amended the statute in a way relevant to the prior interpretation, and if it did, what does the amended statute mean. ${ }^{85}$

Thus, the court can, and should, deduce congressional intent through rigorous textual analysis of the statute. ${ }^{86}$

82

[I]f a product is analytically indefensible-hypothetically at every level imaginable-I am not prepared to conclude, and I don't suggest here, that that means at work necessarily, is judicial activism. It could be sheer incompetence. All I suggest is that when the analysis doesn't hold water, that it is at least fertile field to begin the search for judicial activism. And if it cannot be ascribed to incompetence or laziness, then at least it can be critiqued as a plausible exercise of judicial activism.

Id. at 24 .

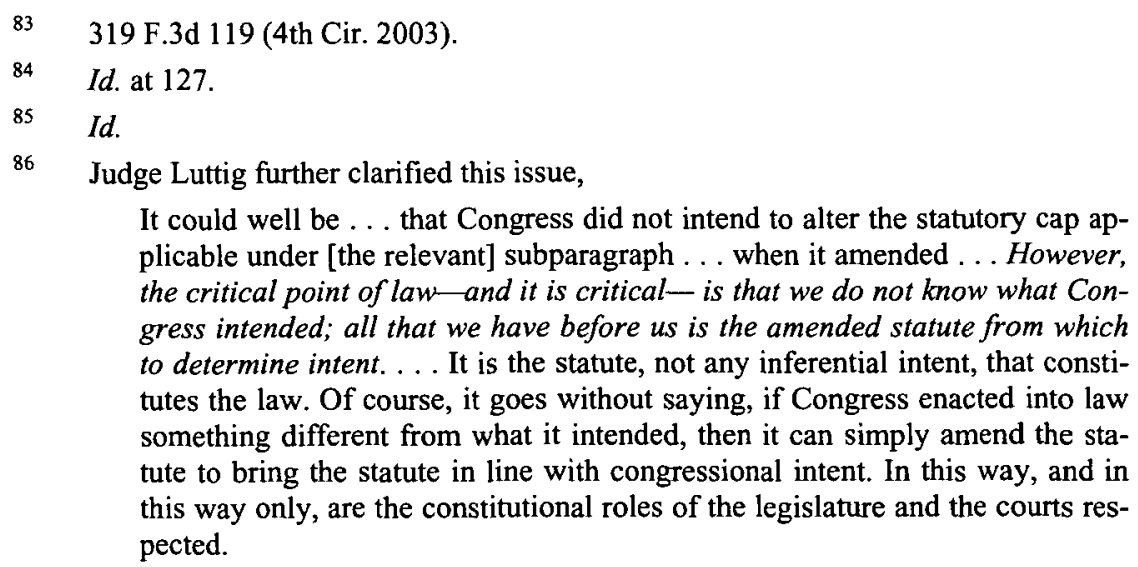

Id. at 128 (emphasis added).

For a concise discussion of the historic development of textualism and how it differs from traditional intentionalism, see John F. Manning, Textualism and Legislative Intent, 91 VA. L. REV. 419 (2005). While classical intentionalists seek to glean Congressional intent not only from the text but also through a careful reading of legislative history, textualists generally eschew legislative history because, as a conceptual matter, there is no single intent to be discovered; legislation is the result of complex deal-making and compromise. Id. Further, textualists fear that legislative history 
In United States $v$. Rhynes, ${ }^{87}$ Judge Luttig again displayed his reliance on textual analysis. In Rhynes, the district judge ruled that counsel violated a court order by discussing the testimony of one witness with another witness who had yet to testify. ${ }^{88}$ The trial court then excluded the witness who had been so coached ${ }^{89}$ The majority in Rhynes held that the district judge abused his discretion in ordering such a sanction, and that it violated the defendant's Sixth Amendment right to call witnesses on his own behalf. ${ }^{90}$ Judge Luttig, in a concurrence, said he would not have reached the Sixth Amendment issue, because he viewed the text as clear on its face.91 In Judge Luttig's judgment, counsel was not bound by the judge's order because the order spoke only of witnesses speaking with one another. ${ }^{92}$ On this reading, counsel was free to communicate the testimony of one witness to another witness who had not yet testified. ${ }^{93} \mathrm{He}$ dismissed the majority's concern with whether the attorney violated "the spirit of the order. ${ }^{, 94} \mathrm{He}$ said courts must be bound by their language. ${ }^{95}$ A judge ought not seek to enforce the "spirit" of the law or seek to divine the "intent" of the law-maker, except as that intent is revealed in and through the text as interpreted through rigorous analysis by one conversant in the relevant arena. ${ }^{96}$ One might sum up much of Judge Luttig's judicial philosophy with the end of his

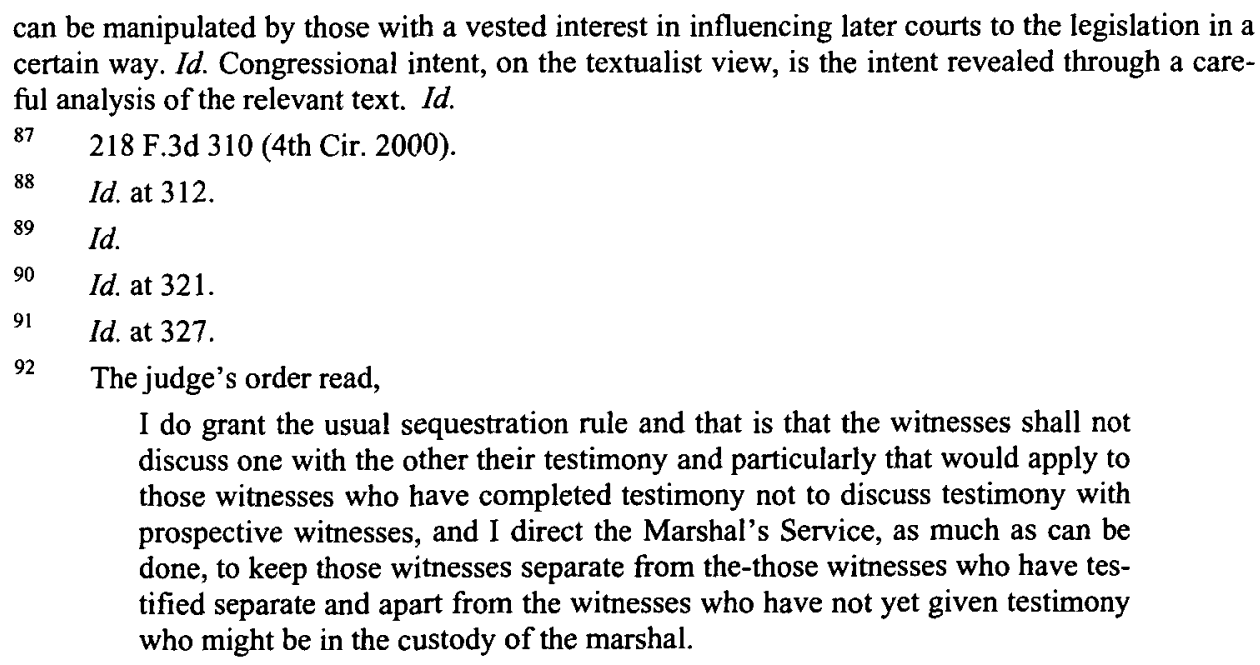

can be manipulated by those with a vested interest in influencing later courts to the legislation in a certain way. Id. Congressional intent, on the textualist view, is the intent revealed through a careful analysis of the relevant text. $I d$.

$87 \quad 218$ F.3d 310 (4th Cir. 2000).

$88 \quad$ Id. at 312.

$89 \quad$ Id.

$90 \quad$ Id. at 321.

$91 \quad$ Id. at 327.

92 The judge's order read,

I do grant the usual sequestration rule and that is that the witnesses shall not discuss one with the other their testimony and particularly that would apply to those witnesses who have completed testimony not to discuss testimony with prospective witnesses, and I direct the Marshal's Service, as much as can be done, to keep those witnesses separate from the-those witnesses who have testified separate and apart from the witnesses who have not yet given testimony who might be in the custody of the marshal.

Id. at 327.

$93 \quad$ Rhynes, 218 F.3d at 327.

$94 \quad I d$. at 327 ("We sit to determine whether laws have been violated, not to assess whether "the spirit' of a law has somehow been offended. In my view, for a judicial body either to punish or to deprive based upon perceived offense to a 'spirit' of an enactment or a judicial order is nothing short of the denial of due process.").

$\begin{array}{ll}95 & \text { Id. } \\ 96 & \text { Id }\end{array}$


concurrence: "Obedience to the language of law . . . is . . the very essence of law."97

Judge Luttig also believed that it is not the judge's role to consider consequences in deciding cases when, in his judgment, the text is clear and unambiguous. In McMellon v. United States, ${ }^{98}$ the court recognized an exception to a waiver of sovereign immunity under the Suits in Admiralty Act ("SIAA"). Judge Luttig wrote a dissent criticizing the majority for considering how failure to recognize an exception would impact the executive branch. ${ }^{100} \mathrm{He}$ explained that he believed "the courts are constitutionally barred from making such a legislative determination ...."101 If Congress clearly and unambiguously waived sovereign immunity, then the courts lack discretion to consider the consequences of that waiver. ${ }^{102}$ If Congress finds those consequences unacceptable, then it is free to change the statute. ${ }^{103}$ The judicial role is to enforce any clear and unambiguous statute that Congress has the constitutional authority to enact. $^{104}$

Although deference to the elected branches ${ }^{105}$ or alignment with sister circuits did not play pivotal roles in Judge Luttig's judicial philosophy, defe-

97 Id. at 328 . In a revealing comment on how they differ in their textual analysis, Judge Wilkinson criticized Judge Luttig's analysis:

My brother Luttig contends that to defer to the district court's interpretation of its own order is to forsake the textualism that properly guides us in the task of statutory construction. This contention is misplaced. The differences between our duty in interpreting a statute and our task in reviewing a district court's interpretation of its own order are significant. It is not possible for us to obtain the views of 100 senators and 435 House members in discerning the meaning of a federal statute. By contrast, it is entirely possible for an attorney to obtain an explanation of an order from a single trial judge, an explanation that is there for the asking. In the pursuit of pure textualism, my brother Luttig supplants the cooperation that should obtain between the bench and bar with a more antagonistic relationship based on exploiting trial court orders for every loophole and imprecision. Just as departing from text undermines the rule of law in the course of statutory interpretation, so too will stripping a district court of the ability to enforce its orders undermine the rule of law at trial.

Id. at 331 .

$98 \quad 387$ F.3d 329 (4th Cir. 2004).

$99 \quad$ Id. at 338.

$100 \quad I d$. at 326.

101 Id. at 381 (emphasis in original).

$102 \quad$ Id. at 382.

$103 \quad I d$. at 377

104 McMellon, 387 F.3d at 365-66. Nor was Judge Luttig concerned that his stance would put the Fourth Circuit at odds with the other circuits. Id. at 380.

105 Deference in this context refers to a judge seeking to avoid striking down a decision by the elected branches. Judge Luttig viewed such restraint as unnecessary. Judges simply need to fulfill their constitutional role of faithfully analyzing the text at issue in light of the constitution and 
rence to Supreme Court precedent did play such a role. For example, in 1998, Judge Luttig granted the Commonwealth of Virginia's request for a stay on a district court's order striking down a Virginia law banning "partial birth" abortion. ${ }^{106}$ However, in 2000, after the Supreme Court overturned a similar law in Nebraska, Judge Luttig, in Richmond Medical Center for Women v. Gilmore, ${ }^{107}$ reversed himself and wrote the Fourth Circuit decision that invalidated the Virginia statute, lifting the stay on the district court's ruling. ${ }^{108}$ This holding ran directly counter to the conservative preference. In fact, the plaintiffs had requested that Judge Luttig recuse himself because he had previously ruled on the state's request to stay the district court order. ${ }^{109}$ But Judge Luttig argued that to recuse himself would be to admit that his personal preferences played a role in his decision-making. ${ }^{10}$ Instead, he explained, "there actually is law independent of each of us, and that, as individual judges, we are bound, and bound equally, by that law."111

In his opinion, he maintained that he understood the Supreme Court's decision in Planned Parenthood v. Casey" decisis" with respect to a woman's fundamental right to choose whether or not to proceed with a pregnancy. ${ }^{113}$ And he clearly articulated his view of the role of the lower courts in relation to the Supreme Court.

As a court of law, ours is neither to devise ways in which to circumvent the opinions of the Supreme Court nor to indulge delay in the full implementation of the Court's opinions. Rather, our responsibility is to follow faithfully its opinions, because that court is, by constitutional design, vested with the ultimate authority to interpret the Constitution. ${ }^{114}$

A judge must bow to precedent regardless of his or her personal preference.

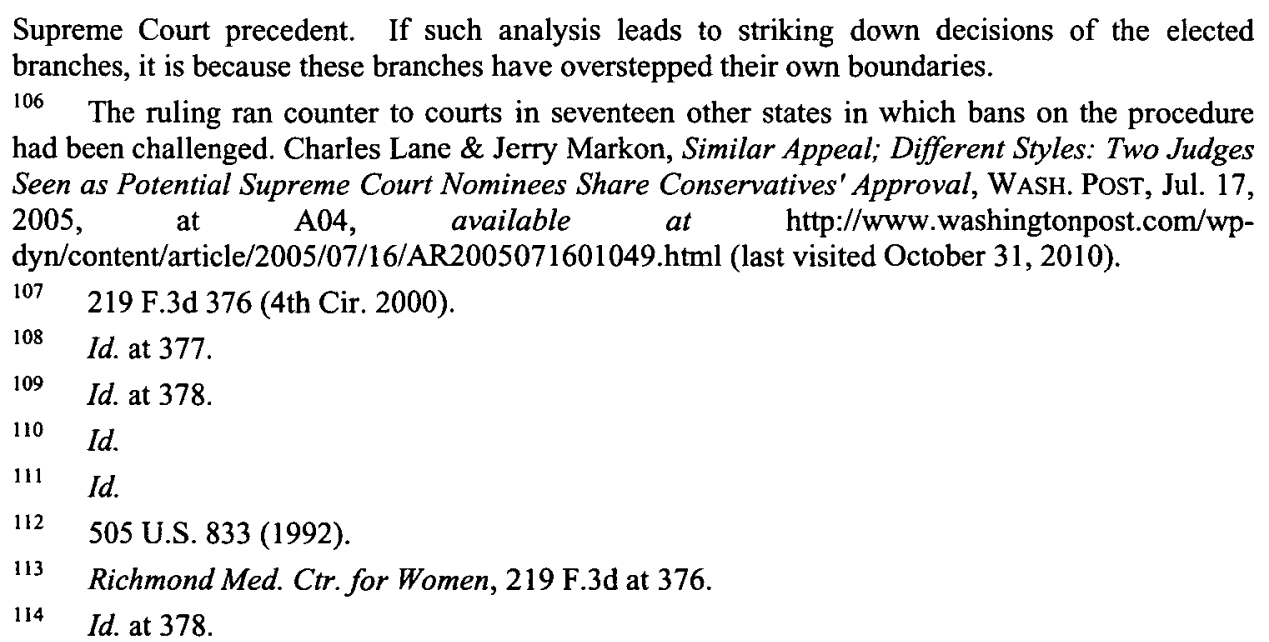


If Judge Luttig's judicial philosophy had a causal impact on his decision in a given case, we expect that the following factors, in appropriate circumstances, were integral in his decision: ${ }^{115}$

(1) The relevant text, rigorously analyzed and largely isolated from social or political context, is of central significance;

(2) Rules and precedent are rigorously adhered to with little concern for practical consequences or how sister circuits have voted; and

(3) Facts are interpreted as narrowly as possible to determine the issue at hand.

If the deployment of the components in these two judges' judicial philosophies were prominent in the judges' articulation of their opinions, then it is plausible to conclude that judicial philosophy had a causal impact on those decisions.

\section{THE CASES}

Each of the following cases is a "political" case falling within one of the following categories: criminal appeal, civil rights, labor, and economic regulation. These cases are "political" because one can predict that judges of particular ideologies will decide these cases in a certain way. The attitudinal model predicts that a "conservative" judge would hold against the defendant and for the prosecution in criminal cases; against the plaintiff and for the defendant in civil-rights cases; against the employee and for the employer in labor cases; and against the government and for the challenger in economic-regulation cases. A "liberal" judge would vote for the opposite outcomes. Because Judges Wilkinson and Luttig were both "conservative" judges, one would predict that their decisions would conform to these outcomes.

An analysis of the cases shows that Judges Wilkinson and Luttig did not always conform to these predictions, and their judicial philosophies help explain why. In each of these cases, Judge Wilkinson's and Judge Luttig's judicial philosophies led them to vote opposite their predicted ideological outcome. In each case, the judges stood fast to those philosophies, and the judges' analyses suggest that judicial philosophy played a significant role in the outcome of the cases.

\footnotetext{
115 That is, without the deployment of some or all of these factors, it is doubtful that he would have reached the decision that he did.
} 
A. Gibbs v. Babbitt, 214 F.3d 483 (4th Cir. 2000)

Gibbs v. Babbitt ${ }^{116}$ showcases the differences between Judge Wilkinson's and Judge Luttig's judicial philosophies. It is a Commerce Clause case, a brand of cases-particularly in the immediate wake of United States v. Lopez ${ }^{117}$ and United States v. Morrison ${ }^{118}$-in which one would predict that two conservative judges would agree on an outcome. However, Judge Wilkinson, writing for the majority, upheld a Department of the Interior regulation as valid under the Commerce Clause ${ }^{119}$ - a result we have labeled as a "liberal" result. Judge Luttig, citing Lopez and Morrison, dissented. ${ }^{120}$

In Gibbs, the court upheld a Fish and Wildlife Service regulation that limited a landowner's ability to "take" red wolves on their property. ${ }^{121}$ In 1973, Congress passed the Endangered Species Act $^{122}$ to protect endangered plants and animals; section 9(a)(1) of the Act prohibited the "taking" of any endangered animal without a permit. ${ }^{123}$ The term "take" was defined as "to harass, harm, pursue, hunt, shoot, wound, kill, trap, capture, or collect, or to attempt to engage in any such conduct." 124 The Act authorized the Fish and Wildlife Service ("FWS") to issue regulations to protect threatened or endangered species. ${ }^{125}$ Reintroduced animals could be labeled as "experimental." 126 These animals were generally treated as "threatened," rather than "endangered.", 127 The FWS could selectively regulate how these animals could be treated, including whether certain animals may be taken on local lands. ${ }^{128}$

In 1986, the FWS issued regulations on the reintroduction of red wolves, an endangered species. The FWS reintroduced the red wolves in eastern North Carolina, which it determined would be the best habitat for the continued survival of the species. It labeled the red wolves "experimental" and promulgated regulations, which prohibited taking of red wolves with certain

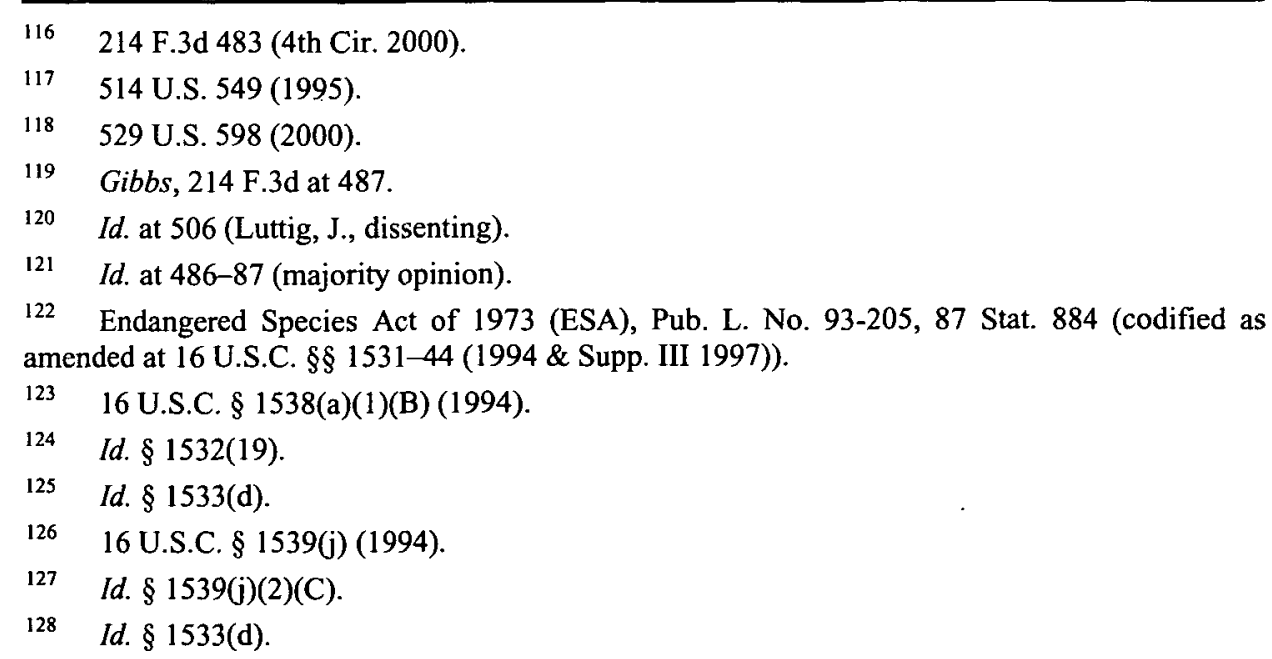


exceptions. Specifically, the FWS relaxed the standards when the taking of the red wolves occurred on private lands. ${ }^{29}$

The plaintiffs, two landowners and two North Carolina counties, challenged the constitutionality of the regulation in federal court. ${ }^{130}$ They claimed that the regulation, as applied to red wolves occupying private land in eastern North Carolina, exceeded the scope of Congress's Commerce Clause power. ${ }^{131}$ The district court sided with the federal government. ${ }^{132}$ It ruled that Congress had the power to regulate conduct that might harm red wolves, because red wolves are "things in interstate commerce because they have moved across state lines and their movement is followed by tourists, academics and scientists."133 The plaintiffs appealed, and the Fourth Circuit affirmed the district court ruling. 134

After outlining the facts of the case, Judge Wilkinson, writing for the majority, clarified his understanding of the Supreme Court's Commerce Clause jurisprudence in the wake of Lopez and Morrison. He argued that the judiciary must ensure that federal statutes and regulations are promulgated under proper constitutional authority. ${ }^{135}$ When federal statutes and regulations rely on the Commerce Clause, the judiciary must evaluate whether the regulated activity sufficiently affects interstate commerce. ${ }^{136}$ Significantly, he clarified that "the courts may not simply tear through the considered judgments of Congress. Judicial restraint is a long and honored tradition and this restraint applies to Commerce Clause adjudications." 137 The Commerce Clause represents a broad grant of federal legislative authority, so that even as the judiciary "must enforce the structural limits of Our Federalism," the judiciary must "also defer to the

129 See Gibbs, 214 F.3d at 488-89 (describing the history of the red wolf's endangered status and the ways in which the taking standard was relaxed). The regulation allowed non-intentional taking of red wolves, such as in defense of a person's life or when the wolves were in the act of killing livestock. An owner was also allowed to harass red wolves on private property, or to take red wolves with written approval if the FWS was unsuccessful in capturing the animals. Id.

In 1990, one of the plaintiffs, Richard Lee Mann, shot a red wolf on his property that he claimed threatened his cattle. The federal government prosecuted Mann under the FWS regulation, and he pled guilty. Id. at 489 . This prosecution sparked opposition to the regulations. The North Carolina General Assembly passed a law allowing private landowners to kill red wolves on their property if the landowners had previously asked FWS to remove the animals from the property. Id. The state law directly conflicted with the federal regulation because it provided less protection than the federal regulation. $I d$.

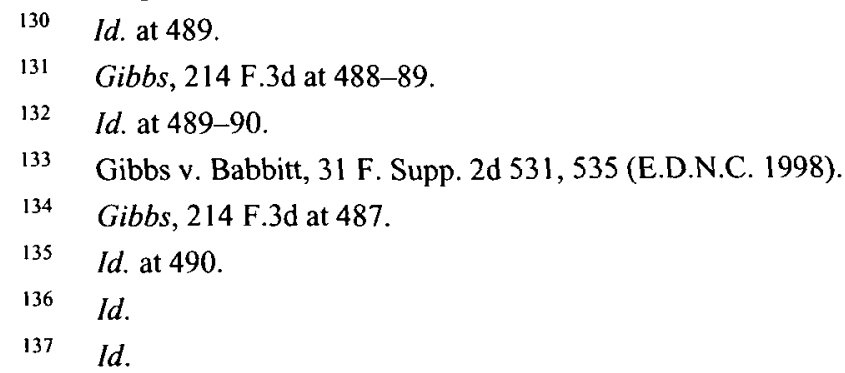


political judgments of Congress . ..."138 Judge Wilkinson argued that the principle underlying Lopez and Morrison is that where a federal regulation (1) only has a tenuous connection to interstate commerce and (2) infringes on an area of traditional state concern, "the courts should not hesitate to exercise their constitutional obligation" and hold that the regulation exceeds Congress's power. ${ }^{139}$ Still, Judge Wilkinson cautioned that courts must not "overstep the judicial role;" he noted that there is something ironic about courts overstepping their constitutional role in an effort to restrain Congress. ${ }^{140}$

Judge Wilkinson analyzed the regulation of taking of red wolves on private property under Lopez's third prong, which provides that the regulated activities must have a substantial impact on interstate commerce. ${ }^{141}$ He said the regulation met this test because red wolves (1) generate revenue from tourism, ${ }^{142}$ (2) generate jobs and deepen knowledge through encouraging scientific research, ${ }^{143}$ and (3) potentially generate revenue through a renewed trade in fur pelts. ${ }^{144}$ Judge Wilkinson leaned on legislative history to bolster these points. ${ }^{145}$ Again, he stressed that courts must defer to Congress's and the administrative agency's judgment regarding the scientific value and commercial impact of red wolves. ${ }^{146}$ These tasks are outside the courts' institutional competence. ${ }^{147} \mathrm{He}$ worried that " $[\mathrm{t}] \mathrm{o}$ overturn this regulation would start courts down the road to second-guessing all kinds of legislative judgments.",148

In addition to holding that the regulation at issue is within the power of Congress under the Commerce Clause, the majority also recognized that it is sustainable as an essential part of a larger regulatory scheme on economic activity, in this case the Endangered Species Act, which depends on such regulations. ${ }^{149}$ Judge Wilkinson argued that separation of powers principles mandated

$138 \quad$ Id. (emphasis added).
$139 \quad$ Id. at 491.
$140 \quad$ Gibbs, $214 \mathrm{~F} .3 \mathrm{~d}$ at 492.
$141 \quad$ Id. at 491.
$142 \quad$ Id. at $493-94$. In making his argument, Judge Wilkinson drew on legislative history to demonstrate that it would not be sufficient for tourism to only protect the red wolves on federal or state land. $I d$. at 494.

$143 \quad$ Id. at 494.

144 Id. at 495. Judge Wilkinson pulled from legislative history to show that controlled exploitation was one of Congress's goals in passing the Endangered Species Act. Id.

145 Id.

146 Gibbs, 214 F.3d at 495.

147 Id. Judge Wilkinson added a fourth point: the taking of red wolves is connected to interstate commerce in the sense that restricting this taking may impede interstate commerce. He noted that it is for Congress, not the courts, to balance economic effects. He also noted that red wolves may actually help farming enterprises, for example, by preying on animals that destroy crops. $I d$.

$148 \quad$ Id. at 497.

149 Gibbs, 214 F.3d at $497-98$ (holding that the regulation at issue must "be evaluated against the overall congressional goal of restoring red wolves and endangered species generally"). 
that courts leave carrying out such a constitutionally authorized regulatory scheme to Congress and executive agencies. ${ }^{150}$

Judge Wilkinson said this regulation was consistent with the Constitution insofar as it properly distinguished what is national from what is local. ${ }^{151}$ The regulation did not infringe on the state's traditional control over wildlife or the state's traditional police power because Congress, with the approval of the Supreme Court, has long regulated private land for environmental and wildlife conservation. ${ }^{152}$

Judge Luttig, in his dissent, framed the issue as follows: "the simple . . question of law for us to decide is whether, assuming its validity under statute, this one particular Fish and Wildlife regulation exceeds Congress' power under the Commerce Clause."153 Judge Luttig disagreed with the majority's grounds for finding that the taking of red wolves on private property would substantially impact interstate commerce. ${ }^{154}$ Specifically, he posited that even the killing of all forty-one red wolves estimated to be on private property would not constitute an economic activity under Lopez and Morrison. ${ }^{155}$ If it was not an economic activity, then aggregation was not permitted. ${ }^{156}$ But, Judge Luttig maintained, even assuming that it was an economic activity, it was not an activity that would substantially impact interstate commerce. ${ }^{157}$ Only by piling inference upon inference could the majority reach its holding. ${ }^{158}$

Judge Luttig clarified that he did not accept the majority's view of the proper role of the judiciary in Commerce Clause cases. ${ }^{159} \mathrm{He}$ characterized the majority's view as saying that "political processes are the safeguard against fed-

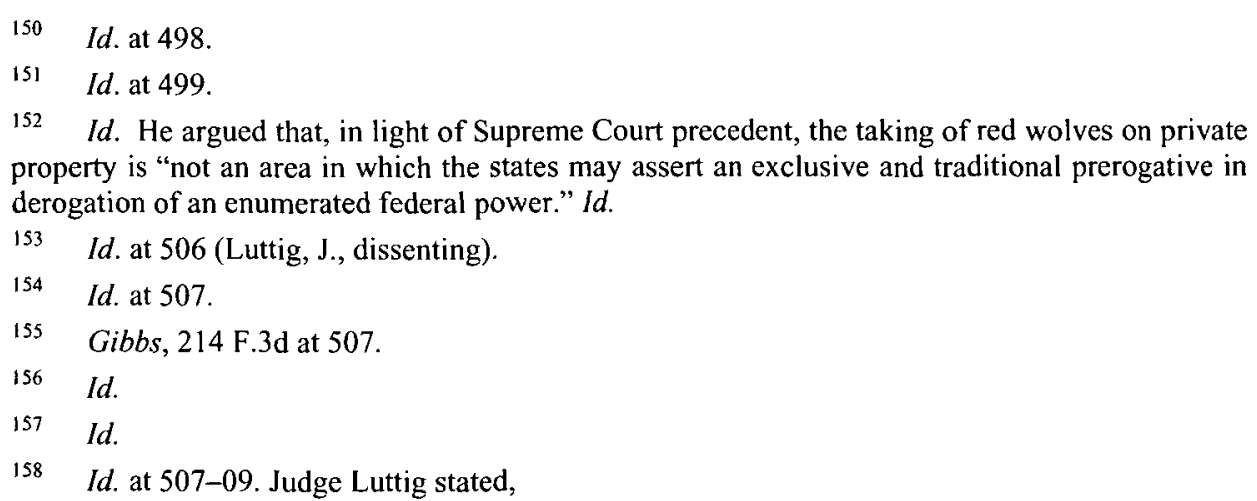

[W] are confronted here with an administrative agency regulation of an activity that implicates but a handful of animals, if even that, in one small region of one state. An activity that not only has no current economic character, but one that concededly has had no economic character for well over a century now. An activity that has no foreseeable economic character at all, except upon the baldest (though admittedly most humorous) of speculation that the red wolf pelt trade will once again emerge as a centerpiece of our Nation's economy.

Id. at 508-09.

$159 \quad$ Id. at 509. 
eral encroachment upon the states."160 However, Judge Luttig argued, it is the courts that must ultimately interpret the Commerce Clause. ${ }^{161}$ And he "would faithfully apply . . . the Supreme Court's landmark decisions in Lopez and Morrison," 162 and hold the regulation unconstitutional.

Judge Wilkinson, in the majority opinion, responded directly to Judge Luttig's dissent. $^{163} \mathrm{He}$ argued that accepting Judge Luttig's position would require the court to "move ... from preserving traditional state roles to dismantling historic federal ones." "64 Further, Judge Wilkinson maintained, Judge Luttig's position would "rework the relationship between the judiciary and its coordinate branches." 165 There is a difference, Judge Wilkinson argued, between the wisdom of legislation and its constitutionality. ${ }^{166}$ While the judiciary has "always started with a presumption in favor of an enactment's constitutionality,"167 Judge Luttig, Judge Wilkinson maintained, reversed the presumption so that the burden lies with those seeking to uphold the enactment.

Judge Wilkinson also took Judge Luttig to task for his "truncated legal universe" that failed to weigh in the judicial balance the national interest in the development of natural resources. ${ }^{168}$ In essence, Judge Luttig's dissent held that scarce resources, or endangered species, are by the very fact that they are scarce or endangered, too trivial to justify protection. ${ }^{169}$ Finally, Judge Wilkinson contended that Judge Luttig's view "works a rent in the fabric of Our Federalism" insofar as it transforms "the reviewing function from a shield protecting state activities into a sword dismembering a long recognized federal one." "170 That is, just as Congress should not usurp traditional state prerogatives, neither should the courts erode the historic role of the federal government in protecting natural resources. ${ }^{171}$ The courts, he argues, should not side with one party or the other, but rather should exercise judicial restraint and step aside to allow Congress to

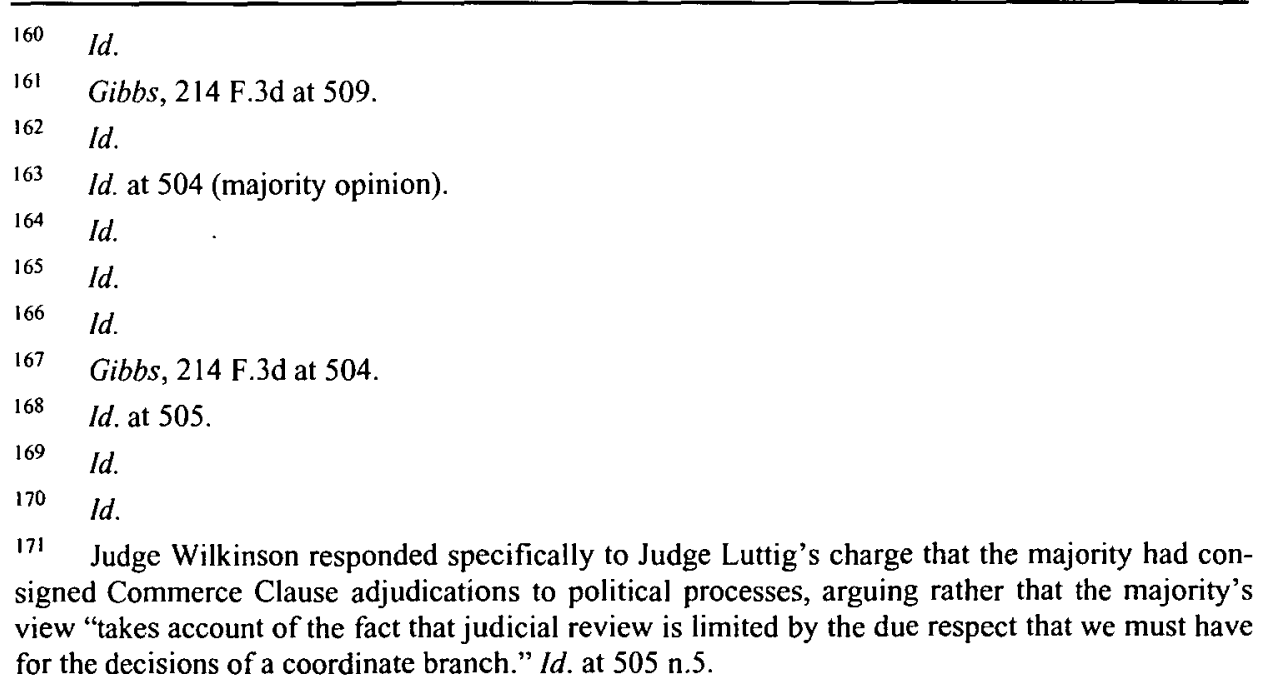


act, as it is constitutionally permitted to do, and promulgate the regulations necessary to enforce the Endangered Species Act. ${ }^{172}$

This exchange between Judges Wilkinson and Luttig encapsulates the contours of their respective judicial philosophies. Luttig saw the case in characteristically sharp terms. In his view, the case simply required faithfully applying the precedent of Lopez and Morrison to the facts of this case. And he characterized the facts themselves in isolation-simply forty-one wolves on private land-from broader social goals or concern for the wider consequences of his ruling. What Judge Wilkinson took to be a "truncated legal universe" was Judge Luttig's attempt to focus on the essential elements in both the law and the facts. In Judge Luttig's judgment, that was the proper limit of the judge's task.

Judge Luttig looked to Supreme Court precedent for guidance and applied the rules he gleaned to the facts, specifically to the forty-one protected wolves on private land. He did not seek to relate these wolves to any larger context in terms of the survival of the species or the Endangered Species Act. Viewing these forty-one wolves in isolation, it is difficult to make an economic argument that would satisfy the Commerce Clause test set out in Lopez, and seen in these terms, he believed the regulation should be struck down.

Judge Wilkinson, also characteristically, viewed this case in complex political and social terms. He drew on the same precedent as Judge Luttig, but understood the import of that precedent very differently because he characterized the facts in terms of Congress's multi-faceted goals in preserving wildlife and the complex means necessary to do so (including regulating wildlife on private property). He explored the consequences of failing to act to regulate takings in this case in terms of its broader implications for the protection of any endangered species. He also carefully examined the federalism issue in terms of traditional state roles and permitted federal roles. And, once he determined which democratic branch, state or federal, was the proper locus of decisionmaking, his view of the properly deferential role of the judiciary in relation to the democratic branches colored his entire analysis.

Judge Wilkinson's analysis encompasses a broader context. He applied the same rules to a very differently understood set of facts. He understood the forty-one wolves on private land as a vital part of the entire population of reintroduced wolves, and this endangered species was part of a broader effort by the federal government to achieve multiple goals (especially through the Endangered Species Act) in terms of wildlife and environmental management. Viewed in this context, the preservation of the wolves on private land was part of an overall scheme that drew tourists, generated scientific interest, and may lead to commercial exploitation of red wolves' pelts. Judge Wilkinson also viewed this protective activity within the context of state-federal relations, and analyzed the traditional, historical role of each body in this arena. Finally, his analysis was contained within his explicit understanding of the judiciary's re-

172

Id. at 506. 
strained role. Viewed in this context, Judge Wilkinson believed the regulation ought to be upheld.

\section{B. United States v. Cotton, 261 F.3d 397 (4th Cir. 2001)}

United States $v$. Cotton, ${ }^{173}$ a criminal appeal, distinguishes Judge Luttig's devotion to text-here, the text of precedent-from Judge Wilkinson's concerns about separation of powers, institutional competency, and practical consequences. The clear conservative outcome would be to side with the prosecution and uphold the criminal convictions. However, Judge Luttig, writing for the majority, went against this preference, and instead remanded the case to district court.

In Cotton, the appellants had been convicted of both conspiracy to distribute and possession with intent to distribute cocaine hydrochloride and cocaine base. ${ }^{174}$ The district court sentenced them to prison for periods ranging from fifteen years to life. ${ }^{175}$ They appealed their sentences on two grounds. They first argued that their sentences should be overturned because the general jury verdict convicting them was ambiguous because it did not specify which drug they had conspired to distribute. ${ }^{176}$ The Fourth Circuit panel rejected this argument without disagreement and upheld their convictions on the grounds that the jury verdict was unambiguous. ${ }^{177}$

The appellants' second argument, however, split the panel. The appellants argued that their sentences violated the Supreme Court's holding in $\mathrm{Ap}$ prendi $v$. New Jersey ${ }^{178}$ because the specific threshold drug quantity, which determined the length of their sentences, was not mentioned in their indictments. ${ }^{179}$ They claimed that drug quantity was an element of their sentencing and that failure to include drug quantity in the indictment affected the fairness of the trial. ${ }^{180}$ The Fourth Circuit held the error was plain and remanded the case for resentencing. ${ }^{181}$

Judge Luttig viewed the salient facts of the cases-the sentencing and the indictment-through the lens of guiding precedent. Since the sentencing went beyond what was explicitly included in the indictment, the case had to go

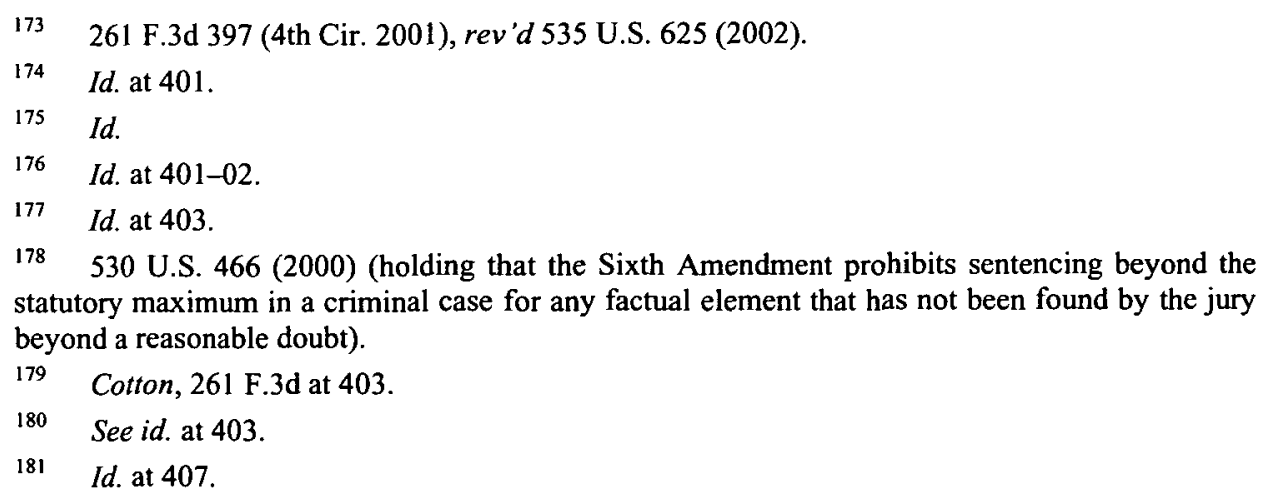


back for re-sentencing. ${ }^{182}$ His opinion centered on Sixth Amendment rights, as interpreted by precedent. He began with a Fourth Circuit case, United States $v$. Promise, ${ }^{183}$ which held that failing to charge drug quantity in an indictment and failing to submit the issue of quantity to the jury is plain error. ${ }^{184}$ He read the facts in Promise to be sufficiently similar to these facts to conclude that the district court in this case committed plain error. ${ }^{185}$

Having found plain error, Judge Luttig looked at several Supreme Court cases to determine the proper remedy. He rejected the government's argument that the facts in this case established the necessary quantities for an aggravated drug trafficking offense ${ }^{186}$ and concluded that the cases required re-sentencing the appellants. ${ }^{187}$ For Judge Luttig, the text of precedent controlled the outcome. He said, "While the government may well be correct as a factual matter, the quantum of evidence is not a relevant consideration when the error stems from a defect in the indictment." 188 He formalistically distinguished the roles of the petit jury and the grand jury. ${ }^{189}$ Even if the petit jury could have found the appellants guilty, it lacked authority to usurp the grand jury's duty to issue an indictment. $^{190}$

Dissenting in part, Judge Wilkinson accepted the government's argument that the sentences should stand because the evidence proved drug quantity. ${ }^{191}$ While he considered the precedent relied upon by the majority, his dissent highlighted separation of powers and public policy grounds (including a powerful concern for the broader consequences of this case). ${ }^{192}$ He explained that "it would constitute a manifest injustice to reduce these defendants' sentences when the evidence undeniably demonstrates that they committed the greater statutory offense," and he would "decline to notice the error."193 Concerned that

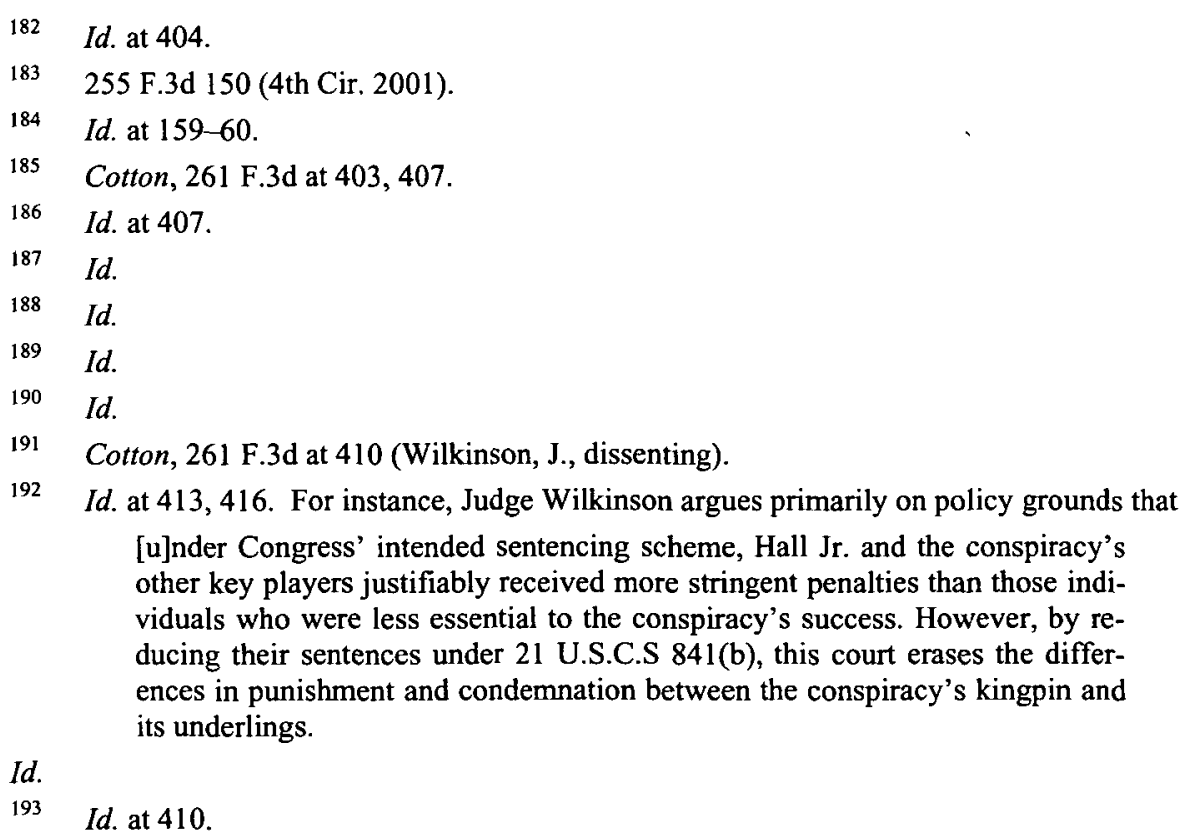


the majority's opinion would harm the ability of the government to prosecute drug crimes, his opinion focused on the overwhelming evidence collected by law enforcement. ${ }^{194} \mathrm{He}$ wrote,

In one sweeping motion, this court nullifies the sacrifices made by law enforcement officers, prosecutors, and trial courts in enforcing this country's drug laws. Furthermore, the majority overlooks the ultimate sacrifice paid by the victims of the drug trade. Seen as part of the overall drug problem, the drugs at issue here may be a mere drop in the bucket. But seen in terms of individual lives, the consequences of this sort of drug distribution are incalculable. ${ }^{195}$

Judge Wilkinson preferred to defer to the executive branch and Congress to decide how to fight drugs. ${ }^{196}$ His Cotton dissent falls squarely in line with his philosophy that the democratic branches should make policy decisions and that the judiciary should defer to those decisions. It also evidences his constant concern with the broader practical consequences of the case before himin this case, concern about the ability of the law enforcement to prosecute crimes that had powerfully destructive effects on their victims and entire communities. In his view, the law cannot be properly applied in a given case if one isolates the facts of the case from these wider implications (such as effectiveness of law enforcement and the effect on communities) and the general judicial obligation of deferring to the political branches.

C. Berkley v. Common Council, 63 F.3d 295 (4th Cir. 1995) (en banc)

Berkley v. Common Council ${ }^{197}$ concerned whether city officers had absolute immunity in a $\S 1983$ action for legislative tasks. ${ }^{198}$ The "conservative" outcome in Berkley would be to find immunity for the city, denying the civil rights plaintiffs the ability to challenge the city council's actions in federal court. The case highlights how Judge Luttig's devotion to text and Judge Wilkinson's focus on the democratic process drove the judges to different outcomes.

Employees of the City of Charleston, West Virginia, sued the city council in a $\S 1983$ action for denying a pay increase. ${ }^{199}$ The employees claimed that the city council denied the pay increase because, in the prior mayoral election,

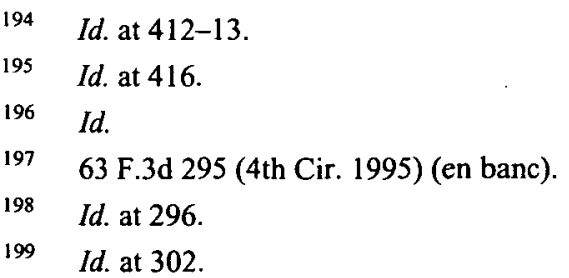


the employees had supported a mayoral candidate that had opposed the candidate that the council had supported. ${ }^{200}$ They claimed this violated their First Amendment rights. ${ }^{201}$ The district court dismissed the suit, ruling that the city had absolute immunity from suit. ${ }^{202}$ The district court ruled that the city had such immunity because it denied the pay increase in the course of passing the city budget, which is a legislative act. ${ }^{203}$

Judge Luttig's majority opinion emphasized his view that no source of law supported granting the city council absolute immunity. He cited the Supreme Court's opinion in Monell v. New York Department of Social Services, ${ }^{204}$ holding that municipalities were "persons" for the purposes of $\S 1983$ suits and could be held monetarily liable. ${ }^{205}$ He noted that, since Monell, municipalities had repeatedly attempted to evade liability under $\S 1983$ by claiming immunity. ${ }^{206}$ However, Judge Luttig remarked, the Supreme Court has "left no doubt that municipalities and local governments are not immune from suits brought under section 1983."207 He cited cases after Monell in which the Court reaffirmed that cities may be liable for their policies. ${ }^{208}$ He wrote, "In the face of such clear and broad pronouncements by the Supreme Court, we have little trouble concluding that a municipality is not immune from section 1983 liability for unconstitutional enactments and other legislative activities of the local legislature." 209

He further explained that the city's legislative acts do not make it immune under legislative immunity because the Supreme Court has addressed that issue. $^{210}$ "[T] he Court," he said, "routinely cites the enactment of legislation as the prototypical government conduct that can give rise to liability . . .."211 Because he found the precedent clear, Judge Luttig explicitly rejected the dissent's attempt to consider consequences to inform their decision. The Court had already considered, and rejected, that policy argument. He wrote, "Ours, however, is not to craft a wise or effective policy, but rather, only to interpret section 1983 consistently with the Supreme Court's interpretation of that statute."212

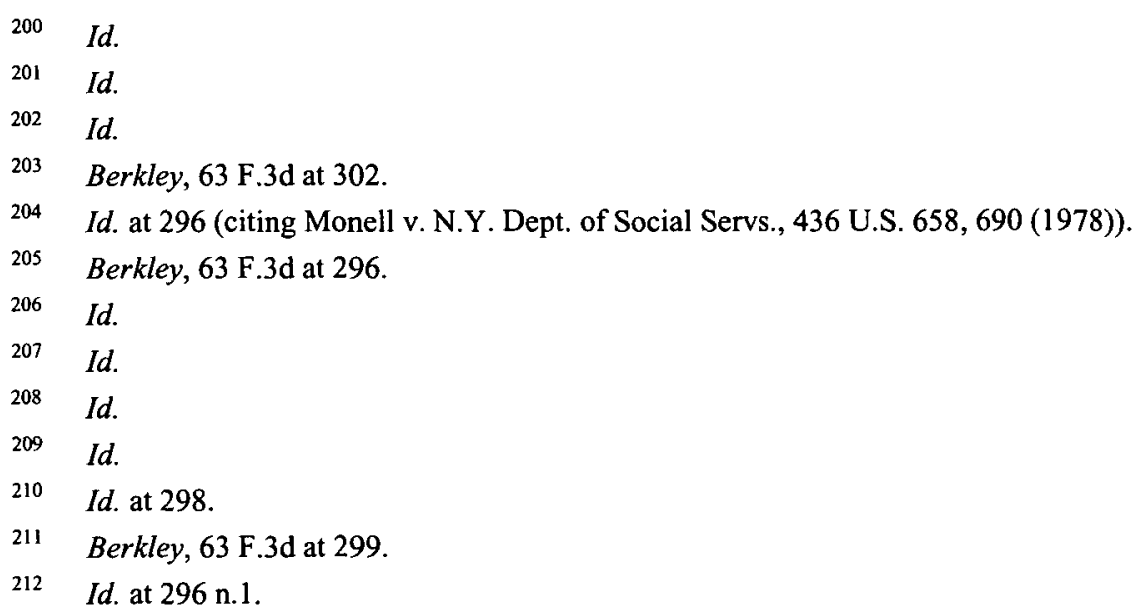


Judge Wilkinson's dissent, however, focused entirely on the practical effect that denying immunity would have on local governments. He characterized the dispute between the employees and the city as a "political dog fight over a municipal budget" that is better left to the political process. ${ }^{213}$ By contrast, the majority decision meant that "the federal courtroom will come to replace the county meeting hall and city council chambers as the cornerstone of American politics."214 The Supreme Court, he explained, could not have intended this result. ${ }^{215}$ In addition, he warned that elected officials would be chilled from exercising discretion out of fear of liability. "Instead of enjoying the freedom to cast votes according to their consciences and the wishes of their constituents," he wrote, "legislators must now look over their shoulders at the possible legal consequences of a vote cast or an argument advanced."216

The federal-state balance was at issue for Judge Wilkinson. Here, a federal court was exposing a local government to federal liability for money damages. In Judge Wilkinson's view, the court had "consigned to federal court the most basic and important acts of a democracy. This amounts, literally, to local government by lawsuit."217 To him, such a derogation from the constitutional balance requires explicit language from Congress. ${ }^{218} \mathrm{He}$ cited Supreme Court precedent requiring clear congressional language before $\S 1983$ suits could interfere with local governments. ${ }^{219} \mathrm{He}$ argued that $\S 1983$ does not contemplate imposing liability on municipal governments for legislative acts: "When Congress passed the law in 1871, it had no idea it would metastasize to this extent." 220 In addition, he contended that the majority position left a "gap ... in the overall structure of defenses to $\S 1983$ actions." ${ }^{, 21}$ He said the Court generally provides municipalities with some immunity under $\S 1983$, but the majority was subjecting municipalities to strict liability. ${ }^{222}$ To him, such consequences required extending absolute immunity to municipal officers when acting in a legislative capacity. ${ }^{223}$

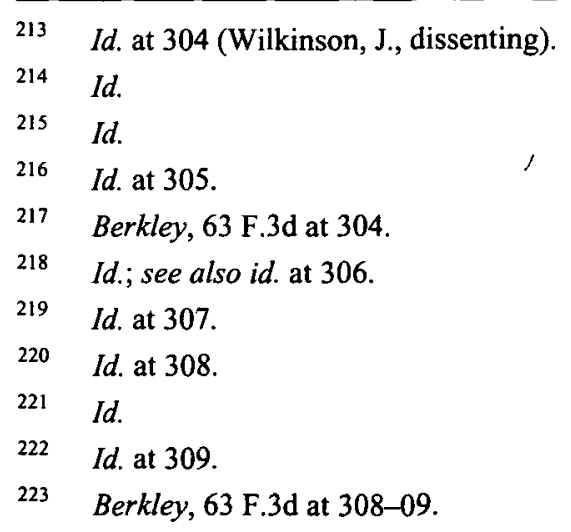


D. First Penn-Pacific Insurance Co. v. Evans, 304 F.3d 345 (4th Cir. 2002)

First Penn-Pacific ${ }^{224}$ is at its heart an abstention case, but it can also be fairly described as an economic-regulation case. By upholding the district court's decision to abstain, the court respected the State of Maryland's interest in regulating an industry. This presents two essentially ideological issues. It presents an issue of whether Maryland can regulate the viatical-settlement industry. But more interestingly, it presents a case where two conservative judges disagreed over the propriety of federal-court abstention.

In First Penn-Pacific, Judge Wilkinson wrote for the majority upholding a district court's dismissal of a claim under Burford abstention. ${ }^{225}$ The court held that the district court did not abuse its discretion when it ruled that a federal court action would disrupt on-going state litigation that was seeking to resolve an important state regulatory issue. ${ }^{26}$ Answer Care, a viatical settlement company, bought life insurance policies from the terminally ill and sold shares in those policies to investors. ${ }^{227}$ First Penn-Pacific, a life insurance company, sued Answer Care. ${ }^{228}$ First Penn-Pacific sought rescission of a policy it sold to one of the terminally ill people that Answer Care worked with on the basis that the policy was fraudulently obtained. ${ }^{229}$ Maryland First Financial intervened in federal court, arguing that the district court should abstain from hearing the suit on the grounds of Burford abstention, because litigation involving these issues was well underway in state court. ${ }^{230}$ It argued that the federal district court hearing the case would interfere with several state court orders. ${ }^{231}$ The district court agreed with Maryland First Financial, and dismissed First Penn-Pacific's claims without prejudice. ${ }^{232}$ First Penn-Pacific appealed. ${ }^{233}$

Judge Wilkinson's opinion centered on the goals of Burford abstention: federalism and comity. ${ }^{234}$ He was concerned about the consequences that the federal-court action would have on the state court resolution of the dispute. ${ }^{235}$

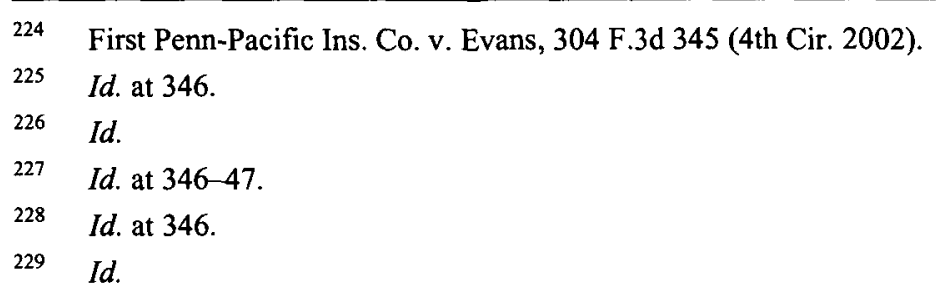

230 First Penn-Pacific, 304 F.3d at 346. In Maryland state court, the Maryland Securities Commissioner had sued Answer Care for securities violations and fraud. Id. The state court had already enjoined Answer Care's business and frozen Answer Care's assets. Id. It had appointed Maryland First Financial Corp. as the receiver for Answer Care's business and had also appointed counsel to sue on the behalf of Answer Care's investors. Id.

$231 \quad$ Id.

232 Id. at $347-48$.

$233 \quad$ Id.

234 Id. at 348 (quoting Quackenbush v. All-State Ins. Co., 517 U.S. 706, 728 (1996)).

235 First Penn-Pacific, 304 F.3d at 349. 
He pointed out early on in his opinion that the standard of review is abuse of discretion. ${ }^{236}$ Noting that Supreme Court precedent does not provide bright-line rules to guide federal courts on when abstention is appropriate, he said the district court did not abuse it discretion by abstaining here. ${ }^{237} \mathrm{He}$ analogized to an abstention case involving a savings and loan and explained that Answer Care was "subject to a highly regulated state process involving the liquidation of its assets." "238 Abstention was appropriate because the federal court action could severely interfere with state-court objectives. ${ }^{239}$ Furthermore, the fact that state law claims were involved and the state court had appointed the receiver under state law favored abstention. ${ }^{240}$

Judge Luttig's dissent focused on a different type of consequence: how the court's decision would change precedent. He characterized the majority's holding as an impermissible extension of Burford abstention. ${ }^{241} \mathrm{He}$ explained that Congress authorized the federal court to hear this case, and no Supreme Court case compelled abstention. ${ }^{242}$ He wrote that "at least on a principled application, Burford abstention would be required in virtually every diversity case by today's opinion, a result supported by no authority, not even those in our Circuit, and certainly none of those relied upon by the majority."243 Judge Luttig distinguished the precedent relied on by the majority. He maintained that that precedent involved a financial crisis that the state dealt with through emergency session legislation. ${ }^{244}$ Here, however, there was no state crisis pending in state court; to the contrary, he said "the receivership here is of the most unexceptional kind." 245 On his view, this case raised no conflict between state and federal action. $^{246}$ Judge Luttig saw this case as one where Congress has granted the federal court jurisdiction to hear the case, and there was nothing in Supreme Court or Circuit precedent that requires abstention. ${ }^{247}$ He concluded by explaining, "As Congress has required by statute, and the Supreme Court has required by decision, I would require the district court to decide this dispute, which was properly before that court for decision. There is no imperative or peculiar need for state court adjudication." 248 Extending Burford to this case would not only

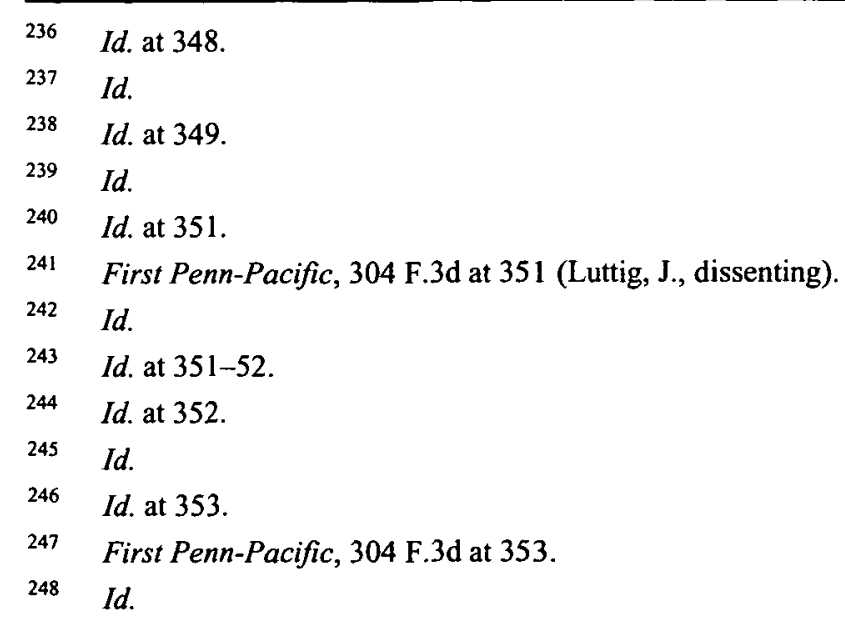


impermissibly stretch what federal law and precedent allow, but it would also set bad precedent for later cases where the text would require courts to follow. ${ }^{249}$

Even though the judges appear backwards in their analysis-Judge Wilkinson focusing solely on these facts and Judge Luttig lamenting consequences-a more nuanced inquiry shows the judges stayed true to their philosophies. Judge Wilkinson's factual approach concentrated on the proper balance in federal-state relations. He worried about the effects that the federal court action would have on state operations. And while Judge Luttig was concerned with consequences, it was the consequences that this holding will have in creating precedent that must be followed in future cases. He was worried about the effects that this holding would have on the law.

This case is unique when compared to the rest of the cases because there is no definable "conservative" outcome. One could argue that abstention is a "conservative" issue-that conservative judges are more likely to abstain. In that case, Judge Wilkinson would be voting for the conservative outcome, and Judge Luttig would be voting for the liberal outcome. However, one could also characterize this as an economic-regulation case, where-by possibly interfering with economic-regulation- Judge Luttig would be voting for the conservative outcome, and Judge Wilkinson would be voting for the liberal outcome. Either way, one would expect two ideologically similar judges to come out the same way. First Penn-Pacific shows how the two judges' judicial philosophies can create an ideological inconsistent outcome.

\section{E. $\quad$ Dixon v. CSX Transportation, 990 F.2d 1440 (4th Cir. 1993)}

In Dixon v. CSX Transportation, ${ }^{250}$ a labor case, the judges' disagreement centered largely on differing interpretations of the facts. ${ }^{251}$ These interpretations display, to some degree, the judges' differing judicial philosophies. Determining who voted conservatively and who voted liberally is difficult. The majority sided with the employer (the conservative outcome), but Judge Wilkinson dissented only in part.

The plaintiffs, Larry Dixon and the Estate of Sally Dixon, sued CRX on a Federal Employer's Liability Act ("FELA") claim and two state law claims. Mr. Dixon was brain damaged and rendered quadriplegic when his vehicle was struck by a CRX train at a railroad crossing. ${ }^{252} \mathrm{Mr}$. Dixon was a traveling agent for a railroad association, of which CSX Transportation was a member. ${ }^{253}$ The plaintiffs argued that Mr. Dixon was a CSX employee, as FELA defines that

$\begin{array}{ll}249 & I d . \\ 250 & 990 \text { F.2d } 1440 \text { (4th Cir. 1993). } \\ 251 & I d . \text { at } 1442 . \\ 252 & I d . \\ 253 & I d .\end{array}$


term, and so eligible to recover under FELA. ${ }^{254}$ Mr. Dixon also sued for personal injury under state law and Mrs. Dixon sued for loss-of-consortium under state law. ${ }^{255}$ At trial, CSX moved to bifurcate the trial, to first determine if $\mathrm{Mr}$. Dixon was a CSX employee and so eligible to sue under FELA. ${ }^{256}$ The district court denied that motion without comment, and the jury found for the plaintiffs on all claims. ${ }^{257}$

On appeal, CSX argued that the district court abused its discretion when it denied CSX's motion to bifurcate the trial. ${ }^{258}$ It maintained that presenting the issues together was prejudicial and confused the jury. ${ }^{259}$ The loss-of-consortium claim, for instance, provided the jury with "inflammatory evidence" regarding the suffering that Mr. Dixon's injury caused his wife, evidence that was irrelevant to determining whether he was a CSX employee when he was injured (i.e., the necessary predicate finding for the FELA claim). ${ }^{260}$ The federal and state law claims each included evidence, CSX argued, that were irrelevant and prejudicial to the alternative claim. CSX also argued that a remand was unnecessary because it was entitled to judgment as a matter of law on both the federal and state law claims-on the federal claims because Mr. Dixon was not a CSX employee, and on the state claims because Mr. Dixon was contributorily negligent as a matter of law. ${ }^{261}$ Finally, CSX argued that the admission of testimony by two of the Dixons' experts was error. ${ }^{262}$

Judge Luttig, writing for the majority, agreed that the district court's refusal to bifurcate the trial was reversible error that had the effect of introducing highly prejudicial evidence and led to jury confusion, thereby denying CSX a fair trial on both the federal and state law claims. ${ }^{263}$ Judge Luttig noted, for example, that "emotional testimony" was heard from Mrs. Dixon on the loss-ofconsortium claim. ${ }^{264}$ The court, therefore, vacated the alternative jury awards against CSX on both the federal and state claims. ${ }^{265}$ The majority also agreed with CSX that Mr. Dixon was not a CSX employee as a matter of law (consequently, there could be no FELA claim), and so the district court erred in submitting the question of whether he was a CSX employee to the jury. ${ }^{266}$

$\begin{array}{ll}254 & \text { Id. } \\ 255 & \text { Id. } \\ 256 & \text { Dixon, } 990 \text { F.2d at } 1443 . \\ 257 & \text { Id. at } 1442 \\ 258 & \text { Id. at } 1143 . \\ 259 & \text { Id. } \\ 260 & \text { Id. } \\ 261 & \text { Id. } \\ 262 & \text { Dixon, } 990 \text { F.2d at } 1452 . \\ 263 & \text { Id. at } 1443 . \\ 264 & \text { Id. } \\ 265 & \text { Id. at } 1454 . \\ 266 & \text { Id. }\end{array}$


However, the majority held that the question of whether Mr. Dixon was contributorily negligent (which would be a complete bar to recovery in North Carolina) was a jury question. ${ }^{267}$ Therefore, the state law claims were remanded to the district court for retrial. ${ }^{268}$ On the question of whether the admission of testimony by the Dixons' experts was error, the majority agreed that the admission of the testimony by a "human factors expert," who, after several days of observation, testified about the behavior of the average motorist at the railroad crossing in question was admitted in error. ${ }^{269}$ The court ruled that the testimony was highly prejudicial; ${ }^{270}$ it showed that Mr. Dixon was more cautious (according to eyewitness testimony) than the average motorist at the crossing, but this conclusion was "wholly irrelevant to the question of whether Mr. Dixon fulfilled his burden to act as a reasonably prudent person, a burden that the North Carolina Supreme Court has defined with specificity."271 The other expert testified on the characteristics of the railroad crossing from an engineering perspective, concluding that it was an extra-hazardous crossing and that CSX should have installed warning lights. ${ }^{272}$ The court held that his testimony was relevant and admissible. ${ }^{273}$ The court concluded that the case was remanded solely for a retrial on the Dixons' state law claims and this trial was to be conducted in accord with the rulings on the expert witnesses. ${ }^{274}$

In his dissent, Judge Wilkinson did not take issue with the majority's holding on Mr. Dixon's federal claims (i.e., the finding that Mr. Dixon was not a CSX employee and so not entitled to any claim under FELA) or with the majority's finding on the admissibility of the engineering expert's testimony. However, Judge Wilkinson would have partially affirmed the judgment of the district court because, focusing on the state law claims, he argued that (1) the majority's opinion itself shows that there was ample reason to credit the jury's finding that Mr. Dixon was not contributorily negligent; ${ }^{275}$ (2) the district court's refusal to bifurcate was not prejudicial with regard to the state law claims because (a) Ms. Dixon's loss-of-consortium claims were relevant to these state law claims, ${ }^{276}$ (b)

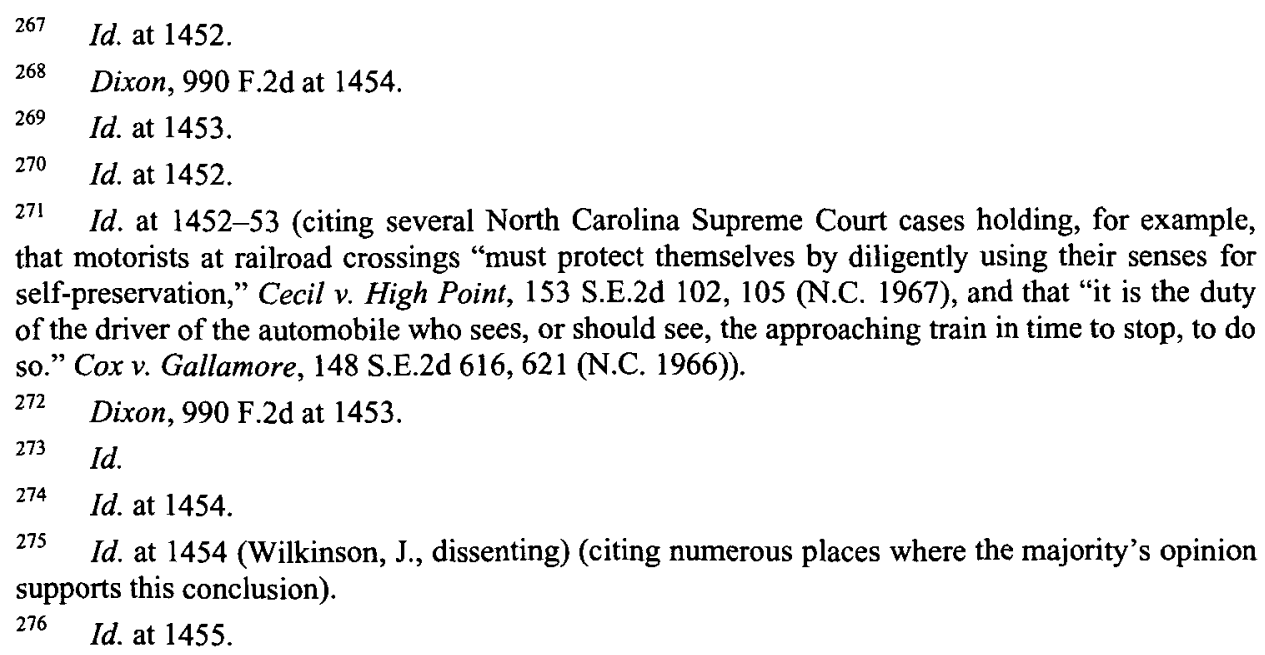
that motorists at railroad crossings "must protect themselves by diligently using their senses for self-preservation," Cecil v. High Point, 153 S.E.2d 102, 105 (N.C. 1967), and that "it is the duty of the driver of the automobile who sees, or should see, the approaching train in time to stop, to do so." Cox v. Gallamore, 148 S.E.2d 616, 621 (N.C. 1966)).

272 Dixon, 990 F.2d at 1453.

273 Id.

274 Id. at 1454.

275 Id. at 1454 (Wilkinson, J., dissenting) (citing numerous places where the majority's opinion supports this conclusion).

276 Id. at 1455. 
the testimony about whether Mr. Dixon was a CSX employee was irrelevant, but not unduly prejudicial, with respect to the state law claims, ${ }^{277}$ and (c) the majority's claim about jury confusion was pure speculation; ${ }^{278}(3)$ the majority's claim that the admission of the testimony of the "human factors expert" was error was, according to Judge Wilkinson, a "startling proclamation" since local custom is often taken in common law as relevant to whether due care was exercised in a given situation. ${ }^{279}$

In short, Judge Wilkinson argued that 'the Dixons' state law claims were properly resolved by the jury, and any errors committed by the district court were too slight to have "affect[ed] the substantial rights of the parties.",280 He noted,

To some, the verdict in this case may seem the product of jury sympathy, but I confess I am not certain how jurors can abandon all feeling for a plaintiff who has been rendered a quadriplegic for life. The question on appeal is not whether the jury was moved by sympathy, but whether it rendered a verdict with a solid foundation in the evidence. I am convinced that it did. ${ }^{281}$

The "liberal" outcome in this case is the one reached in Judge Wilkinson's dissent, which favored the individual over the corporation. The case displays Judge Luttig's penchant for clear rules, and Judge Wilkinson's greater comfort with ambiguity. For Judge Luttig, the fact that the cases were not bifurcated and that failure mixed the testimony relevant to certain of the claims in a manner that may have been prejudicial to other claims was sufficient to conclude that the case should be remanded for retrial. Further, Judge Luttig preferred what he takes to be the clear rules of the North Carolina Supreme Court for determining reasonable care over the murkier common law which allows a place for common practice as relevant to the determination of reasonable care.

Because he apparently agreed that the FELA claim should have been disallowed, and that the failure to bifurcate was an error, Judge Wilkinson focused on the state-law claims. He inquired into how the failure to bifurcate might have been prejudicial as to those claims only. He concluded that any prejudice with respect to those claims was not substantial, and he would have let the district court judgment stand. He, unlike Judge Luttig, found the testimony

277 Id

278 Dixon, 990 F.2d at 1455 . The majority based this conclusion on the fact that the jury came up with the same dollar figure for both the federal and state claims, even though the method for calculating damages were different. See id. at 1444. Judge Wilkinson found this conclusion, on such thin evidence, to be conjectural. But, at any rate, he stated that "the most this argument proves is the need to remand for retrial on damages alone." Id.

279 Id. at 1456.

280 Id. (citing FED. R. CIV. P. 61, Standard for Harmless Error).

281 Dixon, 990 F.2d at 1456. 
as to customary practice relevant to the question of reasonable care, declining to find any hard and fast rules in the North Carolina Supreme Court decisions. The potential for jury sympathy for Mr. Dixon was not troubling to Judge Wilkinson, as it seemed to be Judge Luttig (with his extensive discussion of what he took to be the prejudicial effect of the emotional testimony on the loss-ofconsortium claim).

F. Fieldcrest Cannon, Inc. v. National Labor Relations Board, 97 F.3d 65 (4th Cir. 1996)

A labor case, Fieldcrest Cannon, Inc. v. National Labor Relations Board $^{282}$ brings out the judges' philosophical differences in a fairly subtle fashion. Judge Wilkinson's majority opinion upheld in part and remanded in part a National Labor Relations Board ("NLRB") order against Fieldcrest Cannon, a North Carolina textile manufacturer, for nearly one hundred violations of the National Labor Relations Act ("NLRA"). ${ }^{283}$ The NLRB had ruled that Fieldcrest violated the NLRA during a union organization campaign at two of its textile plants. ${ }^{284}$ Fieldcrest challenged the order for three reasons: first, it claimed that the administrative law judge's findings on the credibility of witnesses were biased in favor of the union; second, it claimed that the evidence did not support the NLRB's findings; and third, it claimed that the NLRB's remedy with respect to the equalization of wages exceeded its authority. ${ }^{285}$

In 1986, Fieldcrest Cannon purchased the business of a major competitor that owned two textile plants in North Carolina. ${ }^{286}$ Both plants had nonunion employees. ${ }^{287}$ In 1991, a union attempted to organize the $6,000 \mathrm{em}$ ployees at the two plants. ${ }^{288}$ Fieldcrest aggressively opposed the union. ${ }^{289}$ Management threatened reprisal against some employees if they supported organization, ${ }^{290}$ and it punished others for their union activities. ${ }^{291}$ Fieldcrest fired ten employees for speaking out on behalf of the union. ${ }^{292}$ The union narrowly lost the vote for unionization. ${ }^{293}$ Fieldcrest subsequently increased wages. However, the wage increase for non-union workers was one percent higher than

\begin{tabular}{ll}
\hline 282 & 97 F.3d 65 (4th Cir. 1996). \\
283 & $I d$. at 67. \\
284 & $I d$. \\
285 & $I d$. \\
286 & $I d$. \\
287 & $I d$. \\
288 & Fieldcrest, 97 F.3d at 67. \\
289 & $I d$. \\
290 & $I d$. \\
291 & $I d$. at 68. \\
292 & $I d$. \\
293 & $I d$.
\end{tabular}


for the union workers. The union charged Fieldcrest with 109 violations of the National Labor Relations Act for its actions during the union election and for discriminating against union employees through wage increases. ${ }^{294}$

The union's claims against Fieldcrest were consolidated before a single administrative law judge ("ALJ") in 1993. . $^{295}$ The ALJ heard testimony from 256 witnesses in a trial that lasted thirty-six days. ${ }^{296}$ The ALJ credited all of the union witnesses on the issue of credibility and none of the Fieldcrest witnesses. ${ }^{297}$ In addition, he made a statement that the union employees' testimony was entitled to "considerable weight" in credibility determinations because "it is unlikely that a current employee will testify falsely against his employer."298 The ALJ also held that Fieldcrest had made numerous violations of the NLRA. ${ }^{299}$ The remedies included mandating a new election, ordering that employees punished by Fieldcrest for their union activities be reinstated, prohibiting Fieldcrest from engaging in unfair labor practices, and requiring Fieldcrest to give union employees a wage increase equal to that it gave non-union employees. $^{300}$

Judge Wilkinson and Judge Luttig disagreed over (1) whether the ALJ's credibility determinations should be upheld and (2) whether the evidence was sufficient to support the claims against Fieldcrest. They agreed that the equalization of wages was not justified under the relevant statute. ${ }^{301}$

On the credibility determinations, Judge Wilkinson, writing for the majority, noted that the Fourth Circuit had clarified that the fact that a witness is an employee testifying adversely to his employer is a factor that should be given "little weight" in determining credibility. ${ }^{302}$ For instance, an employee may be strongly motivated to show that the employer engages in unfair practices, or may be acting in self-interest as a union member. Therefore, the ALJ erred in giving more than a little weight to the witness' status as employees. However, Judge Wilkinson examined the remainder of the record and found sufficient additional indicia of credibility to support the ALJ's findings. ${ }^{303}$ These indicia of credibility included the absence of direct denials on the part of company wit-

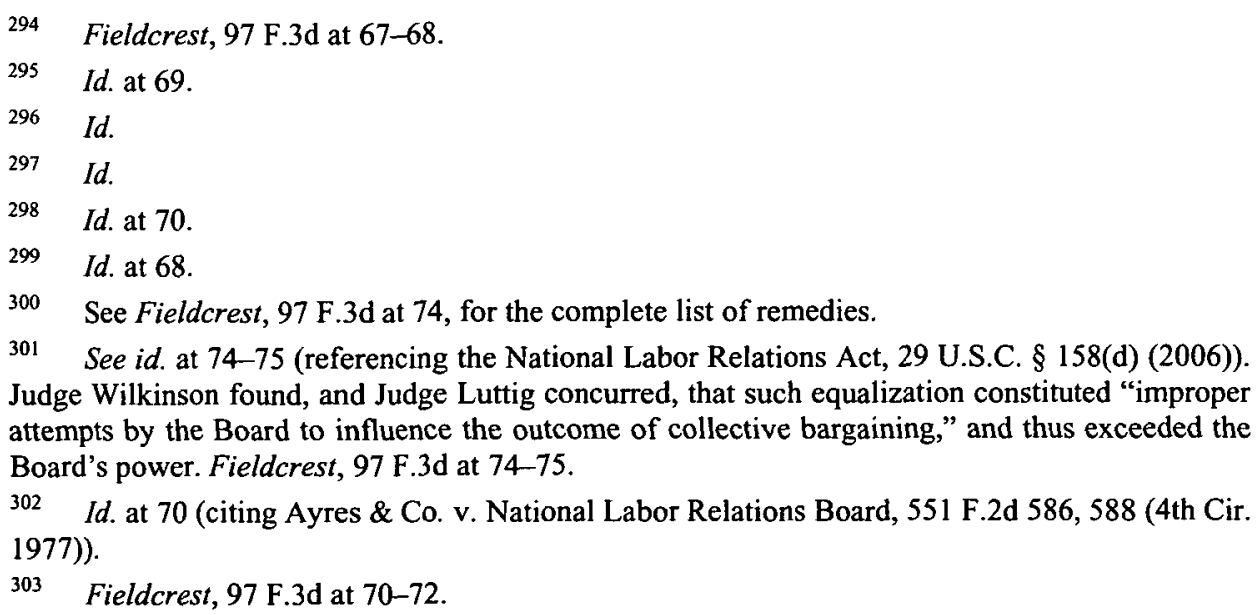


nesses, relevant company witnesses failing to take the stand, testimony of company witnesses that suffered from comparative vagueness or was internally inconsistent, as well as the demeanor of the witnesses. ${ }^{304}$ Wilkinson also noted that "the ALJ was not remiss in observing that the representation campaign [by Fieldcrest] as a whole was marked by an atmosphere of intimidation and hostility toward the union."305

As to the issue of whether sufficient evidence supported the ALJ's substantive findings, Judge Wilkinson argued, "Fieldcrest's attack on the ALJ's credibility determinations misses the forest for the trees. Its attack upon the ALJ fails ultimately to divert attention for the central point of this litigation: the overwhelming evidence against Fieldcrest. The whole of this case is greater even than the sum of its respective parts."306 Judge Wilkinson continued by listing all of the ALJ's findings of Fieldcrest's threats and reprisals, as well as quoting the section of the law that these threats and reprisals violated. ${ }^{307}$

Judge Luttig, in his dissent, contended that no additional indicia of credibility were evident in the record. ${ }^{308}$ Judge Luttig combed the record and attempted to rebut the majority's conclusions point-by-point. For example, he argued "it is impossible to discern in the majority's lone example of 'internal inconsistency' of Company witness testimony any inconsistency at all."309 $\mathrm{He}$ continued by offering details from the example cited by the majority.

Judge Luttig also argued that, even apart from ALJ's crediting the Union employee witnesses over the Company witnesses, "the ALJ found egregious violations of the NLRA where, as a matter of law, there were not even colorable violations." 310 He then listed several examples supporting this claim, adding that "similar examples of the ALJ's errors abound throughout the record." $311 \mathrm{He}$ concluded that the ALJ's errors were so substantial and egregious that the record lacked substantial evidence for the ALJ's findings. ${ }^{312}$

Although this case depends largely on differing readings of the record, the analysis shows the judges' differing judicial philosophies influenced their opinions. As in Cotton, Judge Wilkinson saw the totality of the facts and circumstances as supporting the lower-level decision-maker's conclusion. When convinced that the lower-level decision-maker has adequate basis for its find-

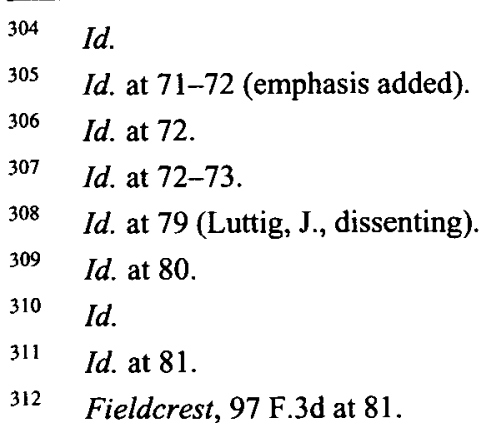


ings, he deferred and left them undisturbed. ${ }^{313}$ This contrasted with Judge Luttig's analysis, which focused exclusively on whether his reading of the facts and the law support the individual findings. He offered no general characterization of Fieldcrest's actions but rather focused on the ALJ's particular findings based on particular facts and asked whether the relevant statute supported those findings, concluding in the negative.

\section{CONCLUSION}

These cases show that judicial philosophy matters. In each case, one would expect two conservative judges to arrive at the same outcome. And in each, there is a strong argument that Judges Wilkinson and Luttig faithfully applied their professed, and differing, judicial philosophies, which compelled them to reach different conclusions. ${ }^{314}$ In none of the cases did the judges deviate from their avowed philosophies; to the contrary, they steadfastly followed them.

Perhaps the dominant strand running through these cases is the differing emphasis placed on text versus context. For instance, Judge Luttig's analysis of text largely examined the text as well as the rule of law in isolation from any larger context. This focus had its corollary in the way he viewed the facts-i.e., largely in terms of the particular facts of the case devoid of social and political context. In contrast, Judge Wilkinson interpreted texts and facts as informed by the broader context, including the relation of the judiciary to the democratic branches, policy considerations, and the practical consequences of a given decision. These cases also reflect the judges' different understandings of the role of rules, as well as their comparative tolerances for ambiguity.

The very structure of this study is an initial challenge to the attitudinal model. It demonstrates that these judges were likely driven to their diverse conclusions at least in part because they adhere to diverse judicial philosophies. These judges' judicial philosophies appear to have played a central role in the outcomes they reached.

The fact that this study includes only two judges and examines only a small number of cases precludes making any far-reaching conclusions about the relation of the respective roles of ideologies and judicial philosophies. But at

\footnotetext{
313 Though it is worth noting that, in this case, he did overturn some of the ALJ's findings where he found that they were clearly unsupported by the evidence or contrary to the law. Id. at 74-77.

314 In addition, it appears as though Judge Luttig's textualism leads him to reach the "liberal" outcome more often than Judge Wilkinson. In the six cases we analyzed, Judge Luttig reached the "liberal" outcome in four of them. This is in congruence with the Manning, Carroll, and Carp study, which found that Judge Luttig voted "liberal" in ten percent less cases than Judge Wilkinson. Manning, Carroll, \& Carp, supra note 10. See also Lane \& Markon, supra note 106 (discussing whether Luttig's textualism made him less conservative). Although a wider analysis of cases would be required to reach a more conclusive result, the cases examined in this manuscript support that conclusion.
} 
least for some judges, in at least some cases, judicial philosophy, and not just ideology, seems to matter in the outcomes they reach.

An interesting question for further study is to determine precisely under what circumstances judicial philosophy matters. Some of the factors that we have discussed in this manuscript, but which deserve further systematic study, include public commitment to a given philosophy and external factors such as the perceived need to distinguish oneself from a competitor. Other factors might be more personal and include such things as individual practices, like keeping a running diary to check on one's consistency between cases of a like kind, or introspection to try to discern the parameters of one's own biases and predilections. There are also interesting normative questions that deserve further exploration, such as: Is consistency in following one's judicial philosophy always the appropriate course to take? If not, what are the criteria for evaluating when deviation is appropriate? And, of course, there is the perennial question of which judicial philosophy is most appropriate or "best."

\section{APPENDIX}

We performed our statistical analysis using the LexisNexis database, which unlike Westlaw, has searchable fields for the name of the person dissenting, concurring, etc. For a few searches, it was helpful to use the Westlaw database, as indicated below. Sample "Search Terms" are included below. A complete list of Search Terms used is on file with the authors and available upon request.

\section{Fourth Circuit:}

En banc decisions: 104

En banc decisions with dissent: 84

Published Fourth Circuit cases between 12/25/1991 and 05/11/2006: 4033 (Westlaw)

Published Reported Fourth Circuit cases between 12/25/1991 and 05/11/2006 with dissents: 683 (Westlaw)

Published panel (i.e., non-en banc) decisions

Total: $4033-104=3929$

With dissents: $683-84=599$

Dissent rate: $599 / 3929=15.3 \%$

\section{Judge Luttig:}

Total dissents: 85

Sample Search Terms: DISSENTBY (Luttig) and not DISPOSITION (petition and "en banc") and date (geq (12/25/1991) and leq (05/11/2006)) 
Panels with published opinions: 1007

Published dissents: 75

Panels with published and unpublished opinions: 10,078

Unpublished dissents: 10

En banc panels: 96

Published/en banc dissents: 12

Dissent rate on published opinions: $75 / 1007=7.5 \%$

Non-en banc panels with published opinions: $1007-96=911$

Published/non-en banc dissents: $75-12=63$

Dissent rate on published/non-en banc opinions: $6.9 \%$

Panels with unpublished opinions: $10,078-1007=9071$

Dissent rate on unpublished opinions: $10 / 9071=0.1 \%$

Dissent rate on published/en banc opinions: $12 / 96=12.5 \%$

\section{Judge Wilkinson:}

Total dissents: 34

Search Terms: DISSENTBY (Wilkinson) and not DISPOSITION (petition and "en banc") and date(geq (12/25/1991) and leq (05/11/2006))

Panels with published opinions: 1003

Sample Search Terms: JUDGES (Wilkinson) and not NOTICE (unpublished) and not DISPOSITION (petition and "en banc") and date(geq $(12 / 25 / 1991)$ and leq (05/11/2006))

Published dissents: 25

Panels with published and unpublished opinions: 5882

Unpublished dissents: 9

En banc panels: 104

Published/en banc dissents: 5

Dissent rate on published opinions: $25 / 1003=2.5 \%$

Non-en banc panels with published opinions: $1003-104=899$

Published/non-en banc dissents: $25-5=20$

Dissent rate on published/non-en banc opinions: $20 / 899=2.2 \%$

Panels with unpublished opinions: $5882-1003=4879$

Dissent rate on unpublished opinions: $9 / 4879=0.2 \%$

Dissent rate on published/en banc opinions: $5 / 104=4.8 \%$

\section{Judges Wilkinson and Luttig:}

Published-Wilkinson and Luttig on panel and Wilkinson dissent: 10

Sample Search Terms: JUDGES(Wilkinson and Luttig) and DISSENTBY (Wilkinson) and not NOTICE (unpublished) and not DISPOSITION (petition and "en banc") and date(geq (12/25/1991) and leq (05/11/2006)) 
Published-Wilkinson and Luttig on panel and Luttig dissent: 25

Sample Search Terms: JUDGES(Wilkinson and Luttig) and DISSENTBY (Luttig) and not NOTICE (unpublished) and not DISPOSITION (petition and "en banc") and date(geq (12/25/1991) and leq (05/11/2006))

Unpublished-Wilkinson and Luttig on panel and Wilkinson dissent: 1

Unpublished-Wilkinson and Luttig on panel and Luttig dissent: 0

Panels together-published and unpublished: 1099

Panels together-published: 254

En banc panels together: 96

En banc panels together-either dissent: 16

En banc panels together-both dissent: 1

En banc panels together-Wilkinson dissent: 5

En banc panels together-Luttig dissent: 12

Published/panel - Wilkinson and Luttig on panel:

Total: $254-96=158$

Wilkinson dissent: 5

Luttig dissent: 13

Wilkinson dissent rate: $5 / 158=3.2 \%$

Luttig dissent rate: $13 / 158=8.2 \%$

\section{Examining the correlation between President Bush's election and dissent rates:}

Total dissent in en banc opinions with Wilkinson or Luttig dissents between 12/25/1991 and 05/11/2006: 16

Total en banc opinions between 12/25/1991 and 05/11/2006: 104

Total en banc opinions with dissents between 12/25/1991 and 05/11/2006: 86

En banc opinions between 12/25/1991 and 01/20/2001: 83

En banc opinions between 12/25/1991 and 01/20/2001 with dissents: 69

En banc opinions between 01/21/2001 and 05/11/2006: 21

En banc opinions between 01/21/2001 and 05/11/2006 with dissents: 17

\section{Judge Luttig:}

En banc opinions between 12/25/1991 and 01/20/2001: 80

Dissent in en banc opinions between 12/25/1991 and 01/20/2001: 8

Dissent rate in en banc opinions between 12/25/1991 and 01/20/2001: $8 / 80=$ $10.0 \%$

En banc opinions between 01/21/2001 and 05/11/2006: 16

En banc dissents between 01/21/2001 and 05/11/2006: 4

Dissent rate on en banc opinions between 01/21/2001 and 05/11/2006: $4 / 16=$ $25.0 \%$

Total published opinions between 12/25/1991 and 01/20/2001: 712

Total published panel opinions between $12 / 25 / 1991$ and $01 / 20 / 2001: 712-80=$ 632

Total published dissents between 12/25/1991 and 01/20/2001: 39

Total published panel dissents between 12/25/1991 and 01/20/2001: $39-8=31$ 
Overall dissent rate between 12/25/1991 and 01/20/2001: $39 / 712=5.5 \%$

Dissent rate in panels decisions between $12 / 25 / 1991$ and $01 / 20 / 2001$ : $31 / 632=$ $4.9 \%$

Total published opinions between 01/21/2001 and 05/1 1/2006: 295

Total published three judge panel opinions between 01/21/2001 and 05/11/2006: $295-16=279$

Total published dissents between 01/20/2001 and 05/11/2006: 34

Total published panel dissents between 01/20/2001 and 05/11/2006: $34-4=30$

Overall dissent rate from $01 / 20 / 2001$ and $05 / 11 / 2006: 34 / 295=11.5 \%$

Dissent rate in panels' opinions between $01 / 20 / 2001$ and $05 / 11 / 2006: 30 / 279=$ $10.8 \%$

En banc opinions between 01/21/2001 and 05/11/2006: 16

En banc dissents between 01/21/2001 and 05/11/2006: 4

Dissent rate en banc opinions between $01 / 21 / 2001$ and $05 / 11 / 2006$ : $4 / 16=$ $25.0 \%$

\section{Judge Wilkinson:}

En banc opinions between 12/25/1991 and 01/20/2001: 83

En banc dissents between 12/25/1991 and 01/20/2001: 3

Dissent rate in en banc opinions between $01 / 21 / 2001$ and $05 / 11 / 2006: 3 / 83=$ $3.6 \%$

En banc decisions between 01/21/2001 and 05/11/2006: 21

En banc dissents between 01/21/2001 and 05/11/2006: 2

Dissent rate in en banc opinions between $01 / 21 / 2001$ and $05 / 11 / 2006: 2 / 21=$ 9.5\%

Total published opinions between 12/25/1991 and 01/20/2001: 651

Total published panel opinions between 12/25/1991 and 01/20/2001: $651-83=$ 568

Total published dissents between 12/25/1991 and 01/20/2001: 15

Overall dissent rate between $12 / 25 / 1991$ and $01 / 20 / 2001: 15 / 651=2.3 \%$

Total published panel dissents between $12 / 25 / 1991$ and $01 / 20 / 2001: 15-3=12$ Dissent rate in panels decisions between $12 / 25 / 1991$ and $01 / 20 / 2001: 12 / 568=$ $2.1 \%$

Total published opinions between 01/21/2001 and 05/11/2006: 311

Total published panel opinions between 01/21/2001 and 05/11/2006: $311-21=$ 290

Total published dissents between 01/20/2001 and 05/11/2006: 8

Overall dissent rate between $01 / 20 / 2001$ and $05 / 11 / 2006: 8 / 311=2.6 \%$

Total published panel dissents between 01/20/2001 and 05/11/2006: $8-2=6$

Dissent rate in panels' opinions 'between 01/20/2001 and 05/11/2006: $6 / 290=$ $2.1 \%$

\section{Judges Luttig and Wilkinson:}


Published panel opinions with Luttig and Wilkinson on panel between 12/25/1991 and 01/20/2001: 188

En banc panels with Luttig and Wilkinson between $12 / 25 / 1991$ and 01/20/2001: 80

En banc panels with Luttig and Wilkinson, with Luttig dissent, between 12/25/1991 and 01/20/2001: 8

Published panel opinions with Luttig and Wilkinson on panel between 12/25/1991 and 01/20/2001: $188-80=108$

Published opinions with Luttig and Wilkinson, with Luttig dissent, between 12/25/1991 and 01/20/2001: 13

Published panel opinions with Wilkinson and Luttig, with Luttig dissent, between 12/25/1991 and 01/20/2001: $13-8=5$

Luttig dissent rate with Wilkinson on panel in panel opinions between 12/25/1991 and 01/20/2001: $5 / 108=4.6 \%$

Published opinions with Luttig and Wilkinson, with Wilkinson dissent, between 12/25/1991 and 01/20/2001: 6

En banc panels with Luttig and Wilkinson, with Wilkinson dissent, between 12/25/1991 and 01/20/2001:3

Published panel opinions with Wilkinson and Luttig, with Wilkinson dissent, between 12/25/1991 and 01/20/2001: $6-3=3$

Wilkinson dissent rate with Luttig on panel in panel opinions between 12/25/1991 and 01/20/2001: $3 / 108=2.8 \%$

Published panel opinions with Luttig and Wilkinson between 01/21/2001 and 05/11/2006: 66

En banc panels with Luttig and Wilkinson between 01/21/2001 and 05/11/2006: 16

En banc panels with Luttig and Wilkinson, with Luttig dissent, between 01/21/2001 and 05/11/2006: 4

En banc panels with Luttig and Wilkinson, with Wilkinson dissent, between 01/21/2001 and 05/11/2006: 2

Published panel opinions with Luttig and Wilksinson between 01/21/2001 and 05/1 1/2006: $66-16=50$

Published opinions with Luttig and Wilksinson, with Luttig dissent, between 01/21/2001 and 05/11/2006: 12

Published panel opinions with Wilkinson and Luttig, with Luttig dissent, between 01/20/2001 and 05/11/2006: $12-4=8$

Luttig dissent rate with Wilkinson on panel in panel opinions between 01/20/2001 and 05/11/2006: $8 / 50=16.0 \%$

Published opinions with Luttig and Wilkinson, with Wilkinson dissent, between 01/21/2001 and 05/11/2006: 4

Published panel opinions with Wilkinson and Luttig, with Wilkinson dissent, between 12/25/1991 and 01/20/2001: $4-2=2$

Wilkinson dissent rate with Luttig on three-judge panel between 01/21/2001 and $05 / 11 / 2006: 2 / 50=4.0 \%$ 


\section{Fourth Circuit-Westlaw [cta4r]:}

Published opinions between 12/25/1991 and 05/11/2006: 4033

Published opinions with dissents between 12/25/1991 and 05/11/2006: 683

Fourth Circuit dissent rate between $12 / 25 / 1991$ and $05 / 11 / 2006$ : $683 / 4033=$ $16.9 \%$

Excluding en banc: $(683-86) /(4033-104)=597 / 3929=15.2 \%$

Published opinions between 12/25/1991 and 01/20/2001: 2765

Dissents in published opinions between 12/25/1991 and 01/20/2001: 429

Fourth Circuit dissent rate between 12/25/1991 and 01/20/2001: 429/2765= $15.5 \%$

Excluding en banc: $(429-69) /(2765-83)=360 / 2682=13.4 \%$

Published opinions between 01/22/2001 and 05/11/2006: 1266

Published opinions between 01/22/2001 and 05/11/2006: 254

Fourth Circuit dissent rate between 01/22/2001 and 05/11/2006: 254/1266 = $20.1 \%$

Excluding en banc: $(254-17) /(1266-21)=237 / 1245=19.0 \%$

\section{Judge Luttig and legislative history:}

Luttig's use of term "legislative history": 22 [hand checked]

Luttig's use of term "legislative history" between 12/25/1991 and 01/20/2001:

17 [hand checked]

Luttig's use of term "legislative history" between 01/21/2001 and 05/11/2006: 5 [hand checked]

Total time on the bench: $(12 / 26 / 1991$ to $05 / 11 / 2006)=\sim 14.38$ years

Average annual use of the term "legislative history" per year: $22 / 14.38=1.5$

Average annual usage from 12/25/1991 to $01 / 20 / 2001: 17 / 9.07=1.8$

Average annual usage from $01 / 21 / 2001$ to $05 / 11 / 2006: 5 / 5.31=0.9$ 